OPEN ACCESS

Edited by:

Marouane Baslam,

Niigata University, Japan

Reviewed by:

Sergio González Nebauer, Universitat Politècnica de València,

Spain

Francisco M. Del Amor, Instituto Murciano de Investigación y Desarrollo Agrario y Alimentario, Spain

*Correspondence:

Yolanda Gogorcena aoiz@eead.csic.es

${ }^{\dagger}$ These authors have contributed equally to this work

Specialty section:

This article was submitted to

Plant Abiotic Stress,

a section of the journal

Frontiers in Plant Science

Received: 03 October 2019

Accepted: 14 January 2020

Published: 28 February 2020

Citation:

Jiménez S, Fattahi M, Bedis K,

Nasrolahpour-moghadam $S$, Irigoyen JJ and Gogorcena Y (2020) Interactional Effects of Climate Change

Factors on the Water Status,

Photosynthetic Rate, and Metabolic

Regulation in Peach.

Front. Plant Sci. 11:43.

doi: 10.3389/fpls.2020.00043

\section{Interactional Effects of Climate Change Factors on the Water Status, Photosynthetic Rate, and Metabolic Regulation in Peach}

\author{
Sergio Jiménez ${ }^{1,2 t}$, Masoud Fattahi ${ }^{1,3 \dagger}$, Khaoula Bedis ${ }^{1}$, \\ Shirin Nasrolahpour-moghadam ${ }^{1,3}$, Juan José Irigoyen $^{4}$ and Yolanda Gogorcena ${ }^{1 *}$ \\ ${ }^{1}$ Laboratory of Genomics, Genetics and Breeding of Fruit Trees and Grapevine, Department of Pomology, Estación \\ Experimental de Aula Dei-Consejo Superior de Investigaciones Cientificas, Zaragoza, Spain, ${ }^{2}$ Bayer AG, Crop Science \\ Division, Research and Development, Environmental Science Field Solutions, Monheim, Germany, ${ }^{3}$ Department of \\ Agriculture, Shahrekord University, Shahrekord, Iran, ${ }^{4}$ Departamento de Biología Ambiental, Grupo de Fisiología del Estrés \\ en Plantas, Unidad Asociada al CSIC (EEAD, Zaragoza e ICW, Logroño), Facultad de Ciencias, Universidad de Navarra, \\ Pamplona, Spain
}

Environmental stress factors caused by climate change affect plant growth and crop production, and pose a growing threat to sustainable agriculture, especially for tree crops. In this context, we sought to investigate the responses to climate change of two Prunus rootstocks (GF677 and Adesoto) budded with Catherina peach cultivar. Plants were grown in $15 \mathrm{~L}$ pots in temperature gradient greenhouses for an 18 days acclimation period after which six treatments were applied: $\left[\mathrm{CO}_{2}\right.$ levels (400 versus $700 \mu \mathrm{mol} \mathrm{mol}{ }^{-1}$ ), temperature (ambient versus ambient $+4^{\circ} \mathrm{C}$ ), and water availability (well irrigated versus drought)]. After 23 days, the effects of stress were evaluated as changes in physiological and biochemical traits, including expression of relevant genes. Stem water potential decreased under drought stress in plants grafted on GF677 and Adesoto rootstocks; however, elevated $\mathrm{CO}_{2}$ and temperature affected plant water content differently in both combinations. The photosynthetic rate of plants grafted on GF677 increased under high $\mathrm{CO}_{2}$, but decreased under high temperature and drought conditions. The photosynthetic rates of plants grafted onto Adesoto were only affected by drought treatment. Furthermore, in GF677-Catherina plants, elevated $\mathrm{CO}_{2}$ alleviated the effect of drought, whereas in those grafted onto Adesoto, the same condition produced acclimation in the rate. Stomatal conductance decreased under high $\mathrm{CO}_{2}$ and drought stress in both grafted rootstocks, and the combination of these conditions improved water-use efficiency. Changes in the sugar content in scion leaves and roots were significantly different under the stress conditions in both combinations. Meanwhile, the expression of most of the assessed genes was significantly affected by treatment. Regarding genotypes, GF677 rootstock showed more changes at the molecular and transcriptomic level than did Adesoto rootstock. A coordinated shift was found between the physiological status and the transcriptomic responses. This study revealed adaptive responses to climate change at the physiological, metabolic, and transcriptomic levels in two Prunus rootstocks 
budded with 'Catherina'. Overall, these results demonstrate the resilient capacity and plasticity of these contrasting genotypes, which can be further used to combat ongoing climate changes and support sustainable peach production.

Keywords: Prunus rootstocks, elevated $\mathrm{CO}_{2}$, warming, drought, osmotic potential, water-use efficiency, soluble sugars, gene expression

\section{INTRODUCTION}

Peach is the third most important temperate fruit tree species of the Rosaceae family, behind apples and pears (FAOSTAT, 2018; http://faostat.fao.org), with China being the largest producer (14.3 million tons), followed by European countries (Spain, Italy, and Greece) and the United States. In 2017, world growth area and production were 1.52 million hectares and 24.7 million tons, respectively. Peach is grown in temperate areas and it is routinely grafted on rootstocks for adaption to different soil and climate conditions. Predictions for new climate scenarios, which include an increase in temperature, alterations in rainfall patterns, and increasing frequency of extreme climate events, are likely to negatively affect global agriculture, especially in Mediterranean regions (IPCC, 2014; FAO, 2016; IPCC, 2018). This concern is especially relevant for peach trees because warming temperatures will impact negatively flowering and production (Gogorcena et al., 2020). In this situation, it is still more critical to choose the correct rootstock-scion combination to cope with the effects of climate change.

In the last century, climate change (high $\mathrm{CO}_{2}$ concentration and temperature, and limited availability of water) has become a major concern for the scientists. According to long-term warming trends since pre-industrial times, temperatures are estimated to have increased by 0.1 to $0.3^{\circ} \mathrm{C}$ per decade across the world (IPCC, 2014; IPCC, 2018) and the mean global temperature is expected to increase by $1.5^{\circ} \mathrm{C}$ between 2030 and 2052 if it continues to rise at the current rate (IPCC, 2018). Atmospheric $\mathrm{CO}_{2}$ concentrations have risen at an accelerated pace since the start of the industrial revolution. For the one thousand years prior to the industrial revolution, $\mathrm{CO}_{2}$ levels were stable at about $280 \mu \mathrm{mol} \mathrm{mol}^{-1}$. Nowadays, this concentration is approximately $53 \%$ higher at $414 \mu \mathrm{mol} \mathrm{mol}^{-1}$ (NOAA Mauna Loa Atmospheric Baseline Observatory, 2019). By the end of this century, it is predicted to reach $700 \mu \mathrm{mol} \mathrm{mol}^{-1}$ (Long et al., 2004; Ainsworth et al., 2008; Salazar-Parra et al., 2018). To cope with such catastrophic climate change, plants need to develop a width spectrum of physiological, biochemical, and molecular programs to rapidly sense change and adapt. In this context, understanding how peach may respond and adapt to future increases in $\mathrm{CO}_{2}$ concentration, temperature, and drought is critical for the agricultural fruit sector.

Previous studies have shown that elevated $\mathrm{CO}_{2}$ concentrations stimulate photosynthetic carbon gain and net primary production (Leakey et al., 2009; Medina et al., 2016; Afzal et al., 2018). However, in long-term experiments, it has been reported that the initial stimulation of photosynthesis decreases due to acclimation of photosynthetic capacity (Leakey et al., 2009; Aranjuelo et al., 2011; Salazar-Parra et al., 2015; Medina et al., 2016), and that environmental or genetic factors predispose plants to greater or lesser variation (reviewed in Arp, 1991; Leakey et al., 2009 and references therein; Medina et al., 2016). Moreover, elevated $\mathrm{CO}_{2}$ improves nitrogen-use efficiency and decreases water use in leaves (Medina et al., 2016). Furthermore, elevated $\mathrm{CO}_{2}$ stimulates leaf dark respiration via a transcriptional reprogramming of metabolism in soybean, but not in other species (Leakey et al., 2009).

It is well accepted that water scarcity will dramatically increase due to climate change and will become a major problem for crop production by limiting the growth and productivity of many crop species. Water limitation in the near future has resulted in strong interest in drought tolerance afforded by rootstocks (Serra et al., 2014), which enable the scion to grow and bear fruit. Plant responses to water limitation are usually monitored through select morphological and physiological traits (Jiménez et al., 2013; Santana-Veira et al., 2016; Fathi et al., 2017; Afzal et al., 2018). Drought inhibits the growth and development of plants, directly affecting the photosynthetic process, resulting in physiological limitations and transcriptional responses that may cause severe decreases in plant yield (Jiménez et al., 2013; Nakashima et al., 2014; Ksouri et al., 2016). Under these stress conditions, there are physiological changes such as reduction of net photosynthesis, and decreases in stomatal conductance and internal $\mathrm{CO}_{2}$ concentrations (Jones, 2007; Cattivelli et al., 2008; Lovisolo et al., 2010). The decrease of stomatal conductance may lead to the reduction of transpiration and water losses as well as to overproduction of reactive oxygen species (ROS) and activation of antioxidant enzymes (Gogorcena et al., 1995; Salazar-Parra et al., 2012; Haider et al., 2017). The accumulation of metabolites such as soluble carbohydrates and proline in leaves and roots of Prunus (Jiménez et al., 2013; Haider et al., 2018), carbohydrates and proline in leaves of pearl millet (Fabbrin et al., 2015), and carbohydrates in citrus rootstocks (Pedroso et al., 2014; SantanaVeira et al., 2016) have all been reported previously as a consequence of drought stress.

Plant responses to elevated $\mathrm{CO}_{2}$ in combination with drought stress and/or temperature increases have been widely studied in different plant species, such as wheat (Erice et al., 2014; Medina et al., 2016), grapevines (Kizildeniz et al., 2015; Salazar-Parra et al., 2015; Martínez-Lüscher et al., 2016; Kizildeniz et al., 2018), alfalfa, soybean, and other plant species (Aranjuelo et al., 2005; Aranjuelo et al., 2006; Baslam et al., 2014; Gray and Brady, 2016 and references therein; Irigoyen et al., 2014; Kelly et al., 2016). 
These earlier studies have found that responses are genotypedependent; however, conflicting experimental results make it difficult to draw general conclusions (Kelly et al., 2016). Some studies have shown positive effects of elevated $\mathrm{CO}_{2}$ on water stress tolerance in some wheat and grapevine genotypes, but these effects were not universal. In wheat, elevated $\mathrm{CO}_{2}$ promoted plant growth and mitigated the deleterious effect of drought on biomass decreases (Medina et al., 2016). In grapevines, a protective effect of $\mathrm{CO}_{2}$ independent of temperature was found concerning oxidative damage (SalazarParra et al., 2015) and plant growth (Kizildeniz et al., 2015). However, in bread wheat genotypes, the effect of $\mathrm{CO}_{2}$ and drought interacted to cause oxidative stress (Bencze et al., 2014), and in other woody species, such as American sycamore, sweet gum, and sugar maple, it negatively affected growth (Gray and Brady, 2016). Other changes under elevated $\mathrm{CO}_{2}$ and drought stress have been described, such as a decrease in Rubisco content and activity, changes in amino acids and $\mathrm{N}$ content, and an increase in carbohydrates in wheat (Aranjuelo et al., 2011), as well as increases in sugar and changes in organic acids and anthocyanin content in grape berries (Kizildeniz et al., 2015).

In fruit plant breeding, rootstocks have been shown to play an important role in drought tolerance by adjusting the water supply to the demands of shoot transpiration. In fact, rootstocks are considered to confer drought and heat tolerance to the scion (Iacono et al., 1998; Meggio et al., 2014; Serra et al., 2014). Morphological and physiological changes were observed in Prunus rootstocks subjected to water deprivation (Solari et al., 2006; Jiménez et al., 2013). Apart from these changes, waterstressed plants may accumulate proline and raffinose in leaves and roots to protect membranes and enzymes, and to deal with the deleterious effects of drought-induced oxidative stress (Jiménez et al., 2013). Proline content in roots and leaves, sorbitol in leaves, and raffinose in roots were all found to be associated with increases in water-use efficiency (Jiménez et al., 2013). Moreover, at the transcriptional level, changes in gene expression were consistently found to support the accumulation of these metabolites in root and leaf tissues in Prunus (Jiménez et al., 2013) and in grapevines (Haider et al., 2017).

As mentioned above, agriculture productivity is strongly affected by drought, temperature increases, and other forms of climate changes (FAO, 2016; Afzal et al., 2018). In the future, plants will not experience individual climate change factors, but will be exposed to several interacting environmental effects at the same time (Gray and Brady, 2016). Plant responses to elevated $\mathrm{CO}_{2}$, temperature, and drought are genotype-dependent (Kizildeniz et al., 2015; Medina et al., 2016; Kizildeniz et al., 2018) and the interactive effects of environmental conditions and genotypic influences cannot be anticipated by studying the effect of each individual climate change factor. For this reason, to investigate plant responses where $\mathrm{CO}_{2}$ concentration, temperature, and water availability can be modulated simultaneously, gradient temperature greenhouses are needed to enable comparisons of current climate with future predictions (Morales et al., 2014). Previous investigations in these facilities have been carried out by a number of authors for different herbaceous plant species (Sanz-Sáez et al., 2012; Sanz-Sáez et al., 2013; Fabbrin et al., 2015) and grapevines (Kizildeniz et al., 2015; Salazar-Parra et al., 2015; Martínez-Lüscher et al., 2016; Kizildeniz et al., 2018; Salazar-Parra et al., 2018), but never for Prunus spp and never taking into consideration rootstock plasticity.

The aim of the present work is to investigate the physiological, biochemical, and molecular responses of two contrasting Prunus rootstocks (GF677 and Adesoto) budded with Catherina peach cultivar to climate change-induced stresses (elevated $\mathrm{CO}_{2}$, elevated temperature, and water deficit). Understanding how rootstocks with different genetic background modulate the response of peach trees under stress conditions and disentangle the underlying molecular mechanisms will be very helpful to develop resilient rootstocks in future breeding programs.

\section{MATERIALS AND METHODS}

\section{Plant Material and Experimental Conditions}

Micropropagated GF677 (Prunus dulcis Miller $\times$ P. persica L. Batsch) and Adesoto ( $P$. insititia L.) rootstock plants were grown for two weeks in $300 \mathrm{~cm}^{3}$ pots containing a peat substrate, then they were micrografted with variety Catherina $(P$. persica $L$. Batsch). Plants were transferred to $15 \mathrm{~L}$ containers with a medium of $1: 1$ sand-peat substrate (TKS-1, Floragard, Oldenburg, Germany) and $2 \mathrm{~g} \mathrm{~kg}^{-1}$ osmocote 14-13-13 (The Scotts Company LLC, Marsyville, OH, USA). Plants were grown for two months in an experimental greenhouse in Zaragoza, Spain $\left(41^{\circ} 43^{\prime} \mathrm{N}, 0^{\circ} 48^{\prime} \mathrm{W}\right)$ under normal day light conditions (14 h light/ $10 \mathrm{~h}$ dark photoperiod) with mean day and night temperatures and humidity of 24 and $18^{\circ} \mathrm{C}$, and 51 and $67 \%$, respectively. Plants were divided randomly into eight groups (20 plants per group) and were transferred to four greenhouses and grown at the University of Navarra (Pamplona, Spain, $42^{\circ} 48^{\prime} \mathrm{N}, 1^{\circ} 40^{\prime} \mathrm{W}$ ). All temperature gradient greenhouses (TGGs) have been designed in a modular way to have a temperature gradient (ambient to $+4^{\circ} \mathrm{C}$ ) and $\mathrm{CO}_{2}$ gassed inside to reach the desired $\mathrm{CO}_{2}$ concentration. Treatments were a combination of two $\mathrm{CO}_{2}$ levels (ambient, approximately $400 \mathrm{ppm}$ and elevated, $700 \mathrm{ppm}$ ), two temperature regimes (ambient temperature and ambient $+4^{\circ}$ C) for $18 \mathrm{~d}$, a period that used for acclimation. Then plants were subjected to two regimes of irrigation. Well-watered plants were maintained at around $80 \%$ of the substrate field capacity. In the water-deficit treatment, plants were watered daily with the $80 \%$ of the evapotranspirated water (Jiménez et al., 2013). Then, in each greenhouse, plants were irrigated and partially irrigated for $23 \mathrm{~d}$. Soil water sensors (Watermark soil moisture sensor, Spectrum Technologies Inc., IL, USA) were placed into the pots and used for irrigation control. Stems (leaves and main shoot) and roots were harvested at $23 \mathrm{~d}$, weighed (fresh weight, FW), and then ovendried (dry weight, DW) at $80^{\circ} \mathrm{C}$ for $48 \mathrm{~h}$. For all treatments, specific leaf area (SLA) was measured and chlorophyll (Chl) concentration per unit leaf area was estimated using a SPAD 502 meter (Minolta Co., Osaka, Japan). Samples from plants submitted to ambient and elevated $\mathrm{CO}_{2}$, ambient and elevated 
temperature, and control and drought stress for $23 \mathrm{~d}$ were randomly collected. Root and leaf tissues from each treatmentplant (four biological replicates) were rinsed in distilled water, immediately frozen in liquid nitrogen and stored at $-80^{\circ} \mathrm{C}$ until their use for the molecular determinations.

\section{Water Status}

A single mature leaf (fifth expanded leaf) of each of the four replicate plants was assayed for stem water potential ( $\Psi$ stem) at day 23 of the experiment. Leaves were enclosed in aluminum foil-covered plastic envelopes to stop transpiration and allow equilibration with $\Psi$ stem 30 min before measurement. Midday $\Psi$ stem were measured using a Schölander-type pressure chamber (PMS instrument, Corvallis, OR, USA). After measurements, leaves were wrapped in aluminum foil, frozen in liquid nitrogen, and stored in plastic bags at $-20^{\circ} \mathrm{C}$ (GarcíaSánchez et al., 2007). After thawing, osmotic potential $(\Psi \pi)$ was measured with a Psychrometer Tru PSi SC10X (Decagon Devices, Inc., Pullman, WA, USA).

Leaf relative water content (RWC) was measured on a mature leaf (sixth expanded leaf) of the four replicate plants. Leaves were immediately weighed to obtain a leaf FW and petioles were submerged into water overnight in the dark. Fully hydrated leaves were reweighed to obtain turgid weight (TW) and dried at $80^{\circ} \mathrm{C}$ for $24 \mathrm{~h}$ to obtain DW. RWC was calculated as $100 \times(\mathrm{FW}-$ DW)/(TW-DW) according to Morgan (Morgan, 1984).

\section{Photosynthetic Parameters}

Photosynthetic rate $\left(A_{\mathrm{N}}\right)$, stomatal conductance $\left(g_{\mathrm{s}}\right)$, intercellular $\mathrm{CO}_{2}$ concentration $(C \mathrm{i})$, and transpiration rate $(E)$ were measured after $23 \mathrm{~d}$ using a portable photosynthesis system (LI-6400XT, Licor, Inc., Lincoln, NE, USA). Measurements were conducted between 10:00 and 12:00 (GMT) in the same leaves used for $\Psi$ stem determinations $(\mathrm{n}=4)$. Parameters were measured with saturating light $\left(1400 \mu \mathrm{mol} \mathrm{m} \mathrm{m}^{-2} \mathrm{~s}^{-1}\right.$ provided by an external light source), $400 \mu \mathrm{mol} \mathrm{mol}^{-1} \mathrm{CO}_{2}$ and $30.5^{\circ} \mathrm{C}$ (average leaf temperature during measurements). Water-use efficiency (WUE) or instantaneous water-use efficiency was calculated as the ratio between the photosynthetic rate and stomatal conductance $\left(A_{\mathrm{N} /} g_{\mathrm{s}}\right)$.

\section{Osmotic-Regulating Compounds: Soluble Sugars and Proline}

Leaf and root soluble sugar content was determined by highperformance liquid chromatography (HPLC). Plant tissue $(n=4)$ was ground to a fine powder in a pre-cooled mortar with liquid nitrogen. Polar compounds from $\sim 0.1 \mathrm{~g} F W$ were extracted into aqueous ethanol at $80^{\circ} \mathrm{C}$, in three steps, each lasting $20 \mathrm{~min}$ (step 1: $0.75 \mathrm{ml}$ of $80 \%$ ethanol; steps 2 and 3: $0.75 \mathrm{ml}$ of $50 \%$ ethanol). The mixture of each step was centrifuged for $10 \mathrm{~min}$ at $4800 \mathrm{~g}$ and slurries were pooled (Moing et al., 2004). The ethanol was allowed to evaporate in a speed-vac and dry extracts were solubilized in $1 \mathrm{ml}$ double-distilled water. Soluble sugars were purified using ion exchange resins (Bio-Rad AG 1-X4 Resin 200-400 chloride form, Bio-Rad AG 50W-X8 Resin 200-400 mesh hydrogen form, Bio-Rad,
Hercules, CA, USA). Samples were concentrated to $0.2 \mathrm{ml}$, filtered and $20 \mu \mathrm{l}$ was injected and analyzed by HPLC, using a Ca-column (Aminex HPX-87C $300 \mathrm{~mm} \times 7.8 \mathrm{~mm}$ column Bio-Rad) flushed with $0.6 \mathrm{ml} \mathrm{min}{ }^{-1}$ double-distilled water at $85^{\circ} \mathrm{C}$ with a refractive index detector (Waters 2410) (Milford, MA, USA). Concentrations of the main sugars (fructose, glucose, raffinose, sorbitol, sucrose, and xylose) were calculated for each sample, using mannitol as an internal standard. Sugar quantification was carried out with Empower Login software from Waters, using commercial standards (Panreac Química S.A. Barcelona, Spain). The amounts of soluble sugars were reported as $\mathrm{mg} \mathrm{g}^{-1} \mathrm{DW}$.

Leaf and root proline were determined using the methodology described previously (Bates et al., 1973; Ábrahám et al., 2010). Plant tissue $(n=4)$ was ground to a fine powder in a pre-cooled mortar with liquid nitrogen. About $0.1 \mathrm{~g}$ of FW per sample was homogenized with 3\% sulfosalicylic acid (Panreac Química S.A.) and the supernatant was reacted with ninhydrine (SigmaAldrich, St. Louis, MO, USA). The absorbance was read at 520 $\mathrm{nm}$ and the free proline concentration was calculated from a calibration curve using proline as a standard (Sigma-Aldrich). Free proline content was reported as $\mathrm{mg} \mathrm{g}^{-1} \mathrm{DW}$.

\section{RNA Isolation and RT-qPCR}

Frozen plant tissue (four biological replicates) was ground to a fine powder in a pre-cooled mortar with liquid nitrogen and subsequently total RNA was isolated from $\sim 100 \mathrm{mg}$ of FW following the protocol of Meisel et al. (2005) with some modifications. After DNase I treatment (Thermo Scientific, Waltham, MA, USA) to eliminate possible genomic DNA contamination, $2 \mu \mathrm{g}$ of total RNA were reverse transcribed using an oligo-(dT) 18 as a primer with RevertAid H Minus first-strand cDNA synthesis system (Thermo Scientific). Samples from cDNA synthesis were used to evaluate the expression of genes involved in sorbitol metabolism and raffinose and proline synthesis. These included sorbitol dehydrogenase $(S D H)$, sorbitol-6-phosphate dehydrogenase (S6PDH), raffinose synthase (SIP1), $\Delta$-1-pyrrolyne-carboxylate synthase (P5CS), $\Delta$ 1-pyrrolyne-carboxylate reductase (P5CR), and ornithine aminotransferase $(O A T)$, which encodes an enzyme that synthesizes a precursor for proline biosynthesis. Also, phosphatidylinositol 4,5-bisphosphate (PIP2), which plays a role in membrane transport, dehydration responsive element binding protein (DREB2), ABA responsive element binding protein (AREB2), and the homeodomain-leucine zipper protein (HAT22) genes were assayed (Supplementary Table 1). Gene sequences were identified by Blastn against the "Peach Genome v1.0 predicted transcripts" database in GDR (http:// www.rosaceae.org) with an $E$-value of $>1 \times 10^{-5}$. Finally, genespecific primers were designed using Primer3Plus (Untergasser et al., 2007). Real-time qPCR was carried out using the Kapa SYBR Fast Maxter Mix (Kapa Biosystems, Cambridge, MA, USA) on a Applied Biosystem 7500 Real Time PCR (Life Technologies, Carlsbad, CA, USA) as described previously (Ksouri et al., 2016). Fluorescence values were baselinecorrected and averaged efficiencies for each gene and 
quantification cycle $(\mathrm{Cq})$ values were calculated using LinRegPCR program (Ruijter et al., 2009). Gene expression was determined with the gene expression Cq difference (GED) formula (Schefe et al., 2006) using Actin 2 as an internal reference gene. Gene expression levels were normalized relative to the values of the drought-tolerant GF677 under control conditions (Jiménez et al., 2013; Ksouri et al., 2016). Normalized data allowed for the comparison of the magnitude of gene expression both across treatments and genotypes.

\section{Statistical Analysis}

Data were evaluated by three-way $\left(2 \mathrm{CO}_{2} \times 2\right.$ temperature $\times 2$ water regimes) analysis of variance (ANOVA) for each genotypetissue with SPSS 25.0.0 (Inc., Chicago, IL, USA). Previously, data were normalized and evaluated by Levene's homoscedasticity test and transformed if necessary. The main treatment parameters $\left(\mathrm{CO}_{2}\right.$, temperature, and drought) were evaluated alone and as interactions. For simplicity in figures, only two-level interactions $\left(\mathrm{CO}_{2} \times \mathrm{T}^{\mathrm{e}}\right)$ or triple $\left(\mathrm{CO}_{2} \times \mathrm{T}^{\mathrm{e}} \times\right.$ drought $)$ were labeled. When treatment interaction terms were significant $(P \leq 0.05)$, means were separated using Duncan's multiple range test at $P \leq 0.05$. Means of two samples were compared using a Student t-test. Regression analysis was carried out by Pearson's correlation.

\section{RESULTS}

\section{Effect of Climate Change on Biomass, Water Status and Physiological Traits Biomass}

After $23 \mathrm{~d}$ of treatment, elevated $\mathrm{CO}_{2}$ and drought modified biomass in plants grafted on both genotypes whereas temperature did not affect plant growth. High $\mathrm{CO}_{2}$ concentrations increased leaf and root DW only in grafted GF677 plants, but decreased shoot/root DW ratio in both genotypes (Table 1). In GF677-Catherina plants, elevated $\mathrm{CO}_{2}$ decreased specific leaf area, while drought decreased the shoot/ root ratio and increased SPAD values. Drought decreased leaf DW in both genotypes and, as a consequence, the shoot/root ratio also decreased.

\section{Stem Water and Osmotic Potentials}

Drought stress reduced stem water and osmotic potentials in Catherina cv. grafted on both rootstocks, GF677 and Adesoto $(P \leq$ 0.001). The $\Psi$ stem in Catherina $\mathrm{CV}$. grafted on Adesoto was also affected by the $\mathrm{CO}_{2}$ concentration and temperature $(P \leq 0.001)$ (Figure 1A). The osmotic potential, $\Psi \pi$, was significantly diminished by elevated $\mathrm{CO}_{2}$ and affected by temperature $(P \leq 0.001)$ in plants grafted on both rootstocks (Figure 1B). Elevated $\mathrm{CO}_{2}$ in plants grafted on Adesoto and elevated temperature in those grafted on GF677 increased stem water and osmotic potentials, respectively.

\section{Photosynthetic Response and Gas Exchange}

The photosynthetic rate $\left(A_{\mathrm{N}}\right)$ of plants grafted on GF677 increased under elevated $\mathrm{CO}_{2}$, but decreased with high temperature and drought (Figure 2). However, when plants
TABLE 1 | Leaf and root dry weight (DW), shoot-to-root ratio, specific leaf area (SLA), and SPAD in control and stressed Prunus rootstocks (GF677 and Adesoto) budded with var. Catherina, after 23 days of treatment.

\begin{tabular}{|c|c|c|c|c|c|c|c|c|}
\hline \multicolumn{2}{|l|}{ GF677 } & \multicolumn{2}{|c|}{$\begin{array}{c}\text { Leaf } \\
\text { DW (g) }\end{array}$} & \multicolumn{2}{|c|}{$\begin{array}{c}\text { Root } \\
\text { DW (g) }\end{array}$} & $\begin{array}{c}\text { Shoot/ } \\
\text { Root } \\
\text { DW } \\
\text { ratio }\end{array}$ & $\begin{array}{c}\text { SLA } \\
\left(\mathrm{cm}^{2} \mathrm{~g}^{-}\right. \\
\left.{ }^{1} \mathrm{DW}\right)\end{array}$ & SPAD \\
\hline \multicolumn{9}{|c|}{ Principal Effects } \\
\hline \multirow[t]{2}{*}{$\mathrm{CO}_{2}$} & $\mathrm{CO}_{2} \mathrm{Amb}$ & 4.8 & $\mathrm{~b}$ & 3.0 & $b$ & $3.3 \mathrm{a}$ & 166 a & 44 \\
\hline & $\mathrm{CO}_{2}$ Elev & 6.3 & a & 4.9 & a & $2.7 \quad b$ & $145 \mathrm{~b}$ & 44 \\
\hline \multirow[t]{2}{*}{ Temperature } & $\mathrm{T}^{\mathrm{e}} \mathrm{Amb}$ & 5.0 & & 3.7 & & 2.9 & 150 & 45 \\
\hline & $\mathrm{T}^{\mathrm{e}} \mathrm{Amb}+4^{\circ} \mathrm{C}$ & 6.0 & & 4.3 & & 3.2 & 160 & 44 \\
\hline \multirow[t]{2}{*}{ Irrigation } & Control & 6.6 & $\mathrm{a}$ & 4.3 & & 3.4 & 159 & $43 \mathrm{~b}$ \\
\hline & Drought & 4.4 & $b$ & 3.6 & & 2.7 & 151 & $46 \mathrm{a}$ \\
\hline \multicolumn{9}{|l|}{ Signification } \\
\hline $\mathrm{CO}_{2}$ & & * & & $\star \star$ & & * & 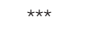 & ns \\
\hline$T^{e}$ & & ns & & ns & & ns & ns & ns \\
\hline Irrigation & & $\star \star$ & & ns & & * & ns & 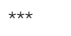 \\
\hline
\end{tabular}

Adesoto

Principal Effects

$\begin{array}{llllllll}\mathrm{CO}_{2} & \mathrm{CO}_{2} \mathrm{Amb} & 4.1 & 2.9 & 3.0 & \text { a } & 157 & 43\end{array}$

$\begin{array}{lrrrrrrr} & \mathrm{CO}_{2} \text { Elev } & 3.6 & 3.5 & 2.4 & \mathrm{~b} & 147 & 42 \\ \text { Temperature } & \mathrm{T}^{\mathrm{e}} \mathrm{Amb} & 3.6 & 3.1 & 2.5 & 146 & 42\end{array}$

$\begin{array}{llllll}\mathrm{T}^{\mathrm{e}} \mathrm{Amb}+4^{\circ} \mathrm{C} & 4.1 & 3.2 & 3.0 & 158 & 42\end{array}$

Irrigation $\quad$ Control $\quad 4.7$ a $\quad 3.2 \quad 3.0$ a $\quad \begin{array}{llllll}155 & 4.0\end{array}$

$\begin{array}{lllllllll} & \text { Drought } & 3.0 & \text { b } & 3.2 & 2.4 & \text { b } & 149 & 42\end{array}$

$\begin{array}{lllll}\text { Signification } & & & \\ \mathrm{CO}_{2} & \mathrm{~ns} & \mathrm{~ns} & & \end{array}$

$\mathrm{T}^{\mathrm{e}}$ ns ns ns ns ns

Irrigation $\quad$ *** ns * $\quad$ ns ns

Three-way ANOVA was performed for linear model, on raw data. Significance: ${ }^{*} P \leq 0.05$, ${ }^{* *} P \leq 0.01,{ }^{* *} P \leq 0.001$ and $n$ s indicates not significant. Comparison means by Duncan's test $(P \leq 0.05)$ were shown for the significant interaction among treatments. Different letters indicate significant differences among data within the same factor. Amb, Ambient; Elev, Elevated; $T^{e}$, Temperature.

These data were presented at the conference of the Spanish Society of Plant Physiology (Fattahi et al., 2019).

were grafted onto Adesoto rootstock, the photosynthetic rate decreased only under drought stress condition. Stomatal conductance $\left(g_{s}\right)$ of grafted plants on GF677 and Adesoto rootstocks decreased with elevated $\mathrm{CO}_{2}$ concentration and drought stress (Figure 2), while transpiration rate $(E)$ decreased only under drought stress condition. Elevated temperature did not affect the Adesoto rootstock.

In both genotypes, the climate change-like conditions, except for elevated temperature in Adesoto, improved the WUE (Figure 2).

Interactive effects among treatments were found for both grafted GF677 and Adesoto rootstocks, between $\mathrm{CO}_{2}$ and temperature $\left(A_{\mathrm{N}}\right.$ in Adesoto, and $g_{\mathrm{s}}$ in both genoypes, Figure 2), between $\mathrm{CO}_{2}$ and drought $\left(A_{\mathrm{N}}, E\right.$ in GF677, and $g_{\mathrm{s}}$ in both genotypes), and between temperature and drought ( $E$ and WUE in both genotypes). A triple interaction was found only in Adesoto-Catherina for transpiration rate ( $E$, Figure 2). Interaction between elevated temperature and drought resulted in a higher WUE in drought stressed plants in both genotypes. 


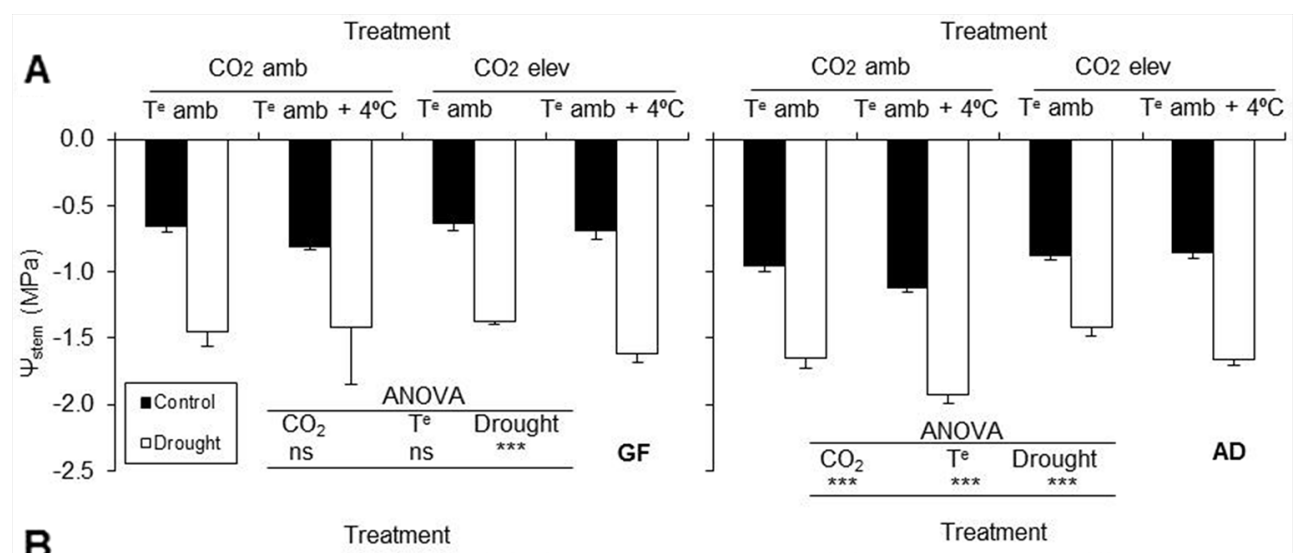

B $\frac{\mathrm{CO} 2 \mathrm{amb}}{\mathrm{T}^{\mathrm{e}} \mathrm{amb} \quad \mathrm{T}^{\mathrm{e}} \mathrm{amb}+4^{\circ} \mathrm{C}} \frac{\mathrm{CO} 2 \mathrm{elev}}{\mathrm{T}^{\mathrm{e}} \mathrm{amb} \quad \mathrm{T}^{\mathrm{e}} \mathrm{amb}+4^{\circ} \mathrm{C}}$

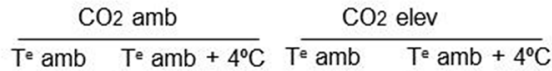
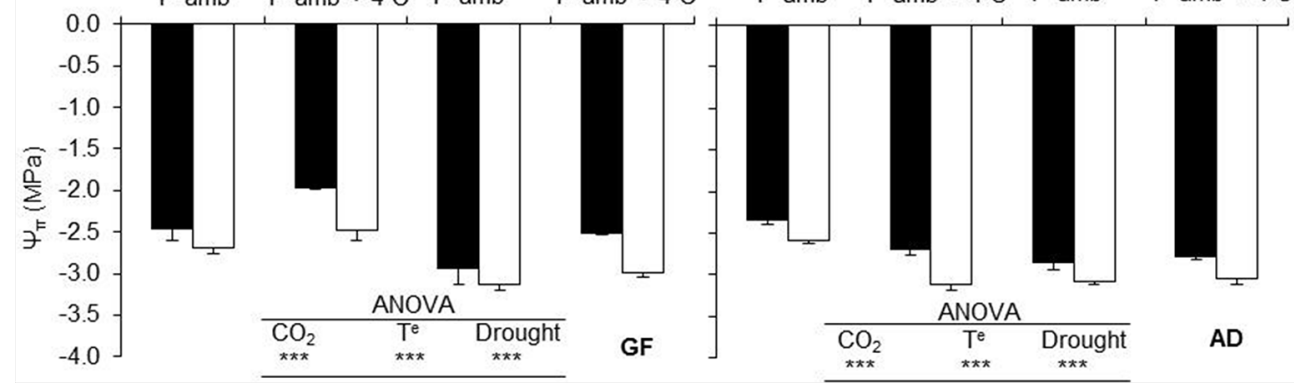

FIGURE 1 | (A) Stem water potential ( $\Psi$ stem) and (B) osmotic potential ( $\Psi \pi$ ) in peach plants (variety Catherina) grafted on GF677 (GF) and Adesoto (AD) and subjected to ambient $\left(\mathrm{amb} \mathrm{CO}_{2}\right)$ and high $\left(\mathrm{CO}_{2}\right.$ elev) $\mathrm{CO}_{2}$, ambient $\left(\mathrm{T}^{\mathrm{e}}\right.$ amb) and high $\left(\mathrm{T}^{\mathrm{e}}\right.$ amb $\left.+4^{\circ} \mathrm{C}\right)$ temperature, and control irrigation and drought for 23 days. Vertical bars indicate the standard error $(n=4)$. Significant differences: ${ }^{\star * \star} P \leq 0.001$ and ns: non-significant.

\section{Effect of Climate Change on Soluble Carbohydrates and Proline Content}

The biochemical responses involving sugars and proline content in roots and leaves of 'Catherina' grafted on both rootstocks (GF677 and Adesoto) subjected to stresses associated with climate change for $23 \mathrm{~d}$ are shown in Tables 2 and 3. In roots, elevated $\mathrm{CO}_{2}$ increased the concentration of glucose and total sugars in both rootstocks, xylose in GF677, and fructose in Adesoto (Table 2). In this study, we noticed that the content of sorbitol and total sugars increased in response to high temperature, but only in roots of Adesoto (Table 2B). In roots, under drought stress condition, raffinose and proline concentration increased in GF677, sorbitol decreased in GF677, but increased in Adesoto rootstock, and fructose decreased in Adesoto (Table 2). The interactive effects between treatments also significantly increased the concentration of sugars (Supplementary Tables 2 and 3). In GF677 rootstock, the interaction between elevated temperature and irrigation increased root raffinose and xylose concentration. In contrast, in Adesoto rootstock, the interaction between elevated $\mathrm{CO}_{2}$ and irrigation increased root glucose content.

Concerning leaves of 'Catherina' grafted on GF677, elevated $\mathrm{CO}_{2}$ significantly increased the concentration of all sugars except xylose, while leaves of 'Catherina' grafted on Adesoto rootstock showed increases only for sucrose (Table 3). Elevated temperature affected only leaves of the GF677-Catherina combination, increasing the content of glucose and decreasing the content of sucrose and proline. Drought had the same effects for sucrose, xylose, and proline in leaves of both combinations. Under drought stress, sucrose decreased, while xylose and proline increased. Furthermore, in the GF677-Catherina combination, this stress condition led to decreased fructose and increased sorbitol content. Interactive effects of $\mathrm{CO}_{2}$ with irrigation in GF677-Catherina led to increases in leaf sorbitol and proline, but in Adesoto-Catherina, the triple interaction $\left(\mathrm{CO}_{2} \times\right.$ temperature $\times$ drought $)$ seemed to maintain the levels of sucrose, sorbitol, and total sugars (Supplementary Tables 4 and 5).

\section{Correlations Between the Physiological Traits, Soluble Sugars, and Proline Content}

Pearson correlation analysis was conducted between the physiological traits and content of biochemical compounds after $23 \mathrm{~d}$ of climate change-like conditions. Osmotic potential $\left(\Psi_{\Pi}\right)$ was negatively correlated with different sugar concentration depending on the tissue and genotype studied. In GF677-Catherina leaves, the content of sucrose, TSS, and 
Figure 2
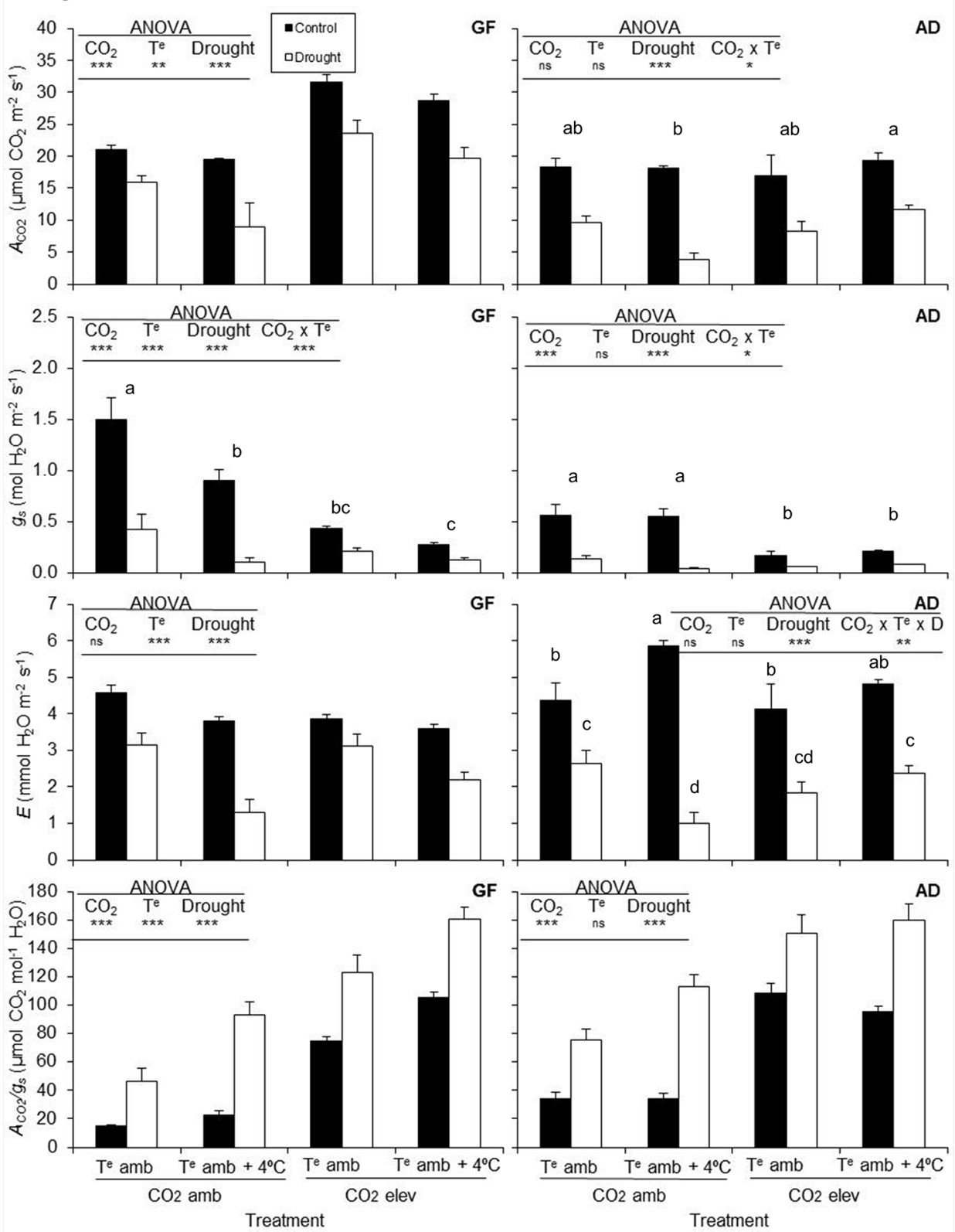

FIGURE 2 | Photosynthetic rate $\left(A_{N}\right)$, stomatal conductance $\left(g_{\mathrm{s}}\right)$, transpiration rate $(E)$, and water-use efficiency $\left(A_{N} / g_{\mathrm{s}}\right)$ in peach plants $($ variety Catherina) grafted on GF677 (GF) and Adesoto (AD) and subjected to ambient $\left(\mathrm{CO}_{2} \mathrm{amb}\right)$ and high $\left(\mathrm{CO}_{2}\right.$ elev) $\mathrm{CO}_{2}$, ambient $\left(\mathrm{T}^{\mathrm{e}}\right.$ amb) and high $\left(\mathrm{T}^{\mathrm{e}}\right.$ amb $\left.+4^{\circ} \mathrm{C}\right)$ temperature, and irrigation control $(\mathrm{C})$, and drought (D) for 23 days. Vertical bars indicate the standard error $(\mathrm{n}=4)$. Significant differences: ${ }^{\star} P \leq 0.05,{ }^{\star \star} P \leq 0.01,{ }^{\star \star \star} P \leq 0.001$ and $\mathrm{ns}$ : non-significant. For the significant double $\left(\mathrm{CO}_{2} \times \mathrm{T}^{\mathrm{e}}\right)$ and triple $\left(\mathrm{CO}_{2} \times \mathrm{T}^{\mathrm{e}} \times \mathrm{D}\right)$ interactions, differences among means are shown with different letters (Duncan's test, $\left.P<0.05\right)$.

proline was negatively correlated with osmotic potential. In the Adesoto-Catherina combination, the content of xylose in leaves, sorbitol and TSS in roots, and proline in both tissues showed negative correlation with osmotic potential. Photosynthetic rate in leaves of 'Catherina' grafted on GF677 and Adesoto were positively correlated with sucrose and proline. Positive correlations were also detected between WUE and content of sorbitol $\left(0.521^{\star \star}, 0.534^{\star \star}\right)$, TSS $\left(0.515^{\star *}, 0.503^{\star *}\right)$, and proline $\left(0.461^{\star *}, 0.474^{\star *}\right)$ in leaves of GF677-Catherina and roots of Adesoto, respectively. Also in roots of plants grafted on GF677, WUE was positively correlated with TSS $\left(0.543^{* *}\right)$ and proline $\left(0.612^{* * *}\right)$. The content of xylose in leaves of Adesoto-Catherina, and raffinose in roots of GF677, were negatively correlated with most of the physiological parameters except for WUE (Table 4). 
TABLE 2 | Root soluble sugars and proline ( $\left.\mathrm{mg} \mathrm{g}^{-1} \mathrm{DW}\right)$ concentration $(\mathrm{n}=4)$ in ambient $\left(\mathrm{amb} \mathrm{CO}_{2}\right)$ and high $\left(\mathrm{CO}_{2}\right.$ elev) $\mathrm{CO}_{2}$, ambient $\left(\mathrm{T}^{\mathrm{e}}\right.$ amb) and high $\left(\mathrm{T}^{\mathrm{e}}\right.$ amb $\left.+4^{\circ} \mathrm{C}\right)$ temperature, and control irrigation and drought-stressed GF677 (A) and Adesoto (B) Prunus rootstocks budded with cv. Catherina, after 23 days of treatment.

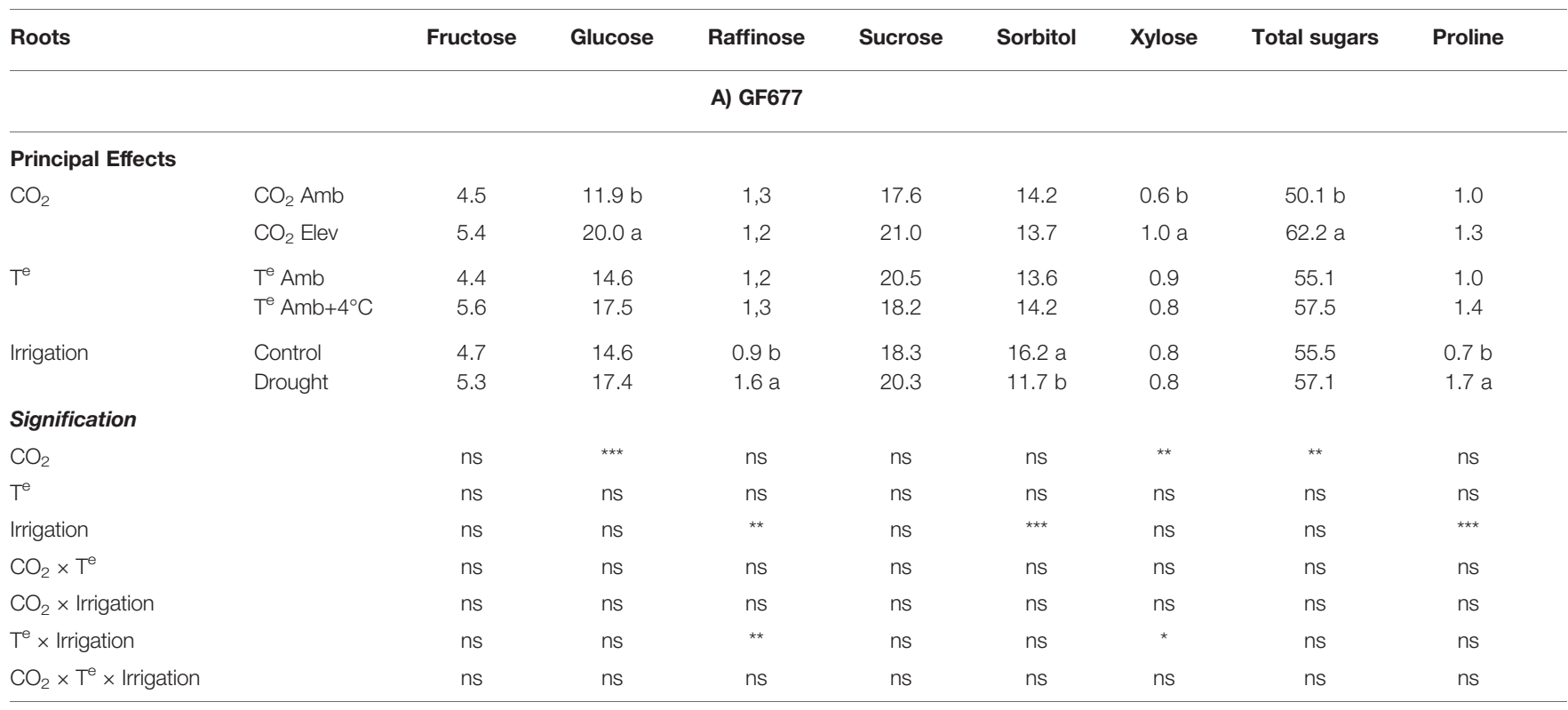

B) Adesoto

\section{Principal Effects \\ $\mathrm{CO}_{2}$ \\ $T^{e}$ \\ Irrigation \\ Signification \\ $\mathrm{CO}_{2}$ \\ $\mathrm{T}^{\mathrm{e}}$ \\ Irrigation \\ $\mathrm{CO}_{2} \times \mathrm{T}^{\mathrm{e}}$ \\ $\mathrm{CO}_{2} \times$ Irrigation \\ $\mathrm{T}^{\mathrm{e}} \times$ Irrigation \\ $\mathrm{CO}_{2} \times \mathrm{T}^{\mathrm{e}} \times$ Irrigation \\ ** \\ $\mathrm{nS}$
$\star \star$ \\ ns \\ ns \\ ns \\ ns $T^{e}$, Temperature. \\ Effect of Climate Change on Transcriptional Responses}

$\begin{array}{lcc}\mathrm{CO}_{2} \mathrm{Amb} & 4.7 \mathrm{~b} & 18.7 \mathrm{~b} \\ \mathrm{CO}_{2} \text { Elev } & 5.8 \mathrm{a} & 23.6 \mathrm{a} \\ \mathrm{T}^{\mathrm{e}} \mathrm{Amb} & 5.0 & 21.4 \\ \mathrm{~T}^{\mathrm{A}} \mathrm{Amb}+4^{\circ} \mathrm{C} & 5.4 & 21.0 \\ \text { Control } & 5.9 \mathrm{a} & 19.7 \\ \text { Drought } & 4.6 \mathrm{~b} & 22.6\end{array}$

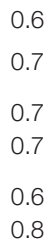

$\begin{array}{lll}* * & * & \mathrm{~ns} \\ \text { ns } & \mathrm{ns} & \mathrm{ns} \\ * * & \mathrm{~ns} & \mathrm{~ns} \\ \mathrm{~ns} & \mathrm{~ns} & \mathrm{~ns} \\ \mathrm{~ns} & \text { **} & \mathrm{ns} \\ \mathrm{ns} & \mathrm{ns} & \mathrm{ns} \\ \mathrm{ns} & \mathrm{ns} & \mathrm{ns}\end{array}$

0.6
0.7
0.7
0.7
0.6
0.8
ns
ns
ns
ns
ns
ns
ns

26.3
30.5
27.4
29.5
30.7
26.4

$\begin{array}{rrrr}18.6 & 0.9 & 70.5 \mathrm{~b} & 0.9 \\ 20.3 & 1.1 & 82.7 \mathrm{a} & 1.0 \\ 15.3 \mathrm{~b} & 0.9 & 71.3 \mathrm{~b} & 0.9 \\ 23.3 \mathrm{a} & 1.1 & 81.4 \mathrm{a} & 1.0 \\ 14.2 \mathrm{~b} & 1.1 & 72.6 & 0.9 \\ 24.4 \mathrm{a} & 1.0 & 80.2 & 1.0\end{array}$

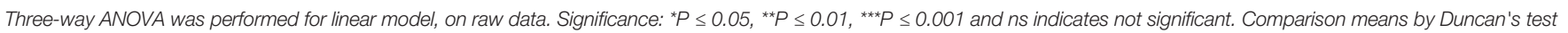

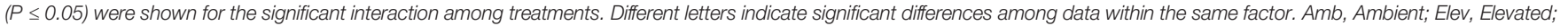

After $23 \mathrm{~d}$ of growth under climate change conditions, samples from roots and scion leaves of 'Catherina' budded on GF677 and Adesoto rootstocks were collected to study the transcriptomic responses. The transcript levels were evaluated by RT-qPCR for nine and seven genes, in roots and leaves, respectively. We focused on the significant changes under stress conditions concerning relative gene expression (RNorm) in both tissues and rootstocks (Tables 5 and $\mathbf{6}$ ).

For roots of GF677 rootstock (Table 5A), we found that the $\mathrm{CO}_{2}$ treatment significantly decreased the transcript level of raffinose synthase (SIP1), which encodes an enzyme involved in raffinose biosynthesis. The temperature treatment strongly affected the expression of genes related to sugar and proline metabolism, as well as other genes associated with the drought stress responses. We observed decrease expression of sorbitol dehydrogenase $(S D H)$ and sorbitol-6-phosphate dehydrogenase (S6PDH), key enzymes of sorbitol catabolism and biosynthesis, respectively. Elevated temperature also decreased the expression of $\Delta-1$ pyrrolyne-carboxylate synthase (P5CS), dehydration responsive element binding protein 2 (DREB2), ABA responsive element binding protein (AREB2), and homeodomain-leucine zipper protein (HAT22). Finally, water deficit in roots of GF677 also diminished the expression of $S D H$ while the normalized expression of $S 6 P D H, \Delta$-1-pyrrolyne-carboxylate synthase (P5CS), and $\Delta$-1-pyrrolyne-carboxylate reductase (P5CR) was upregulated (Table 5A). These results were consistent with the 
TABLE 3 | Scion leaf soluble sugars and proline $\left(\mathrm{mg} \mathrm{g}{ }^{-1} \mathrm{DW}\right)$ concentration $(\mathrm{n}=4)$ in ambient $\left(\mathrm{amb} \mathrm{CO}_{2}\right)$ and high $\left(\mathrm{CO}_{2}\right.$ elev $) \mathrm{CO}_{2}$, ambient $\left(\mathrm{T}^{\mathrm{e}}\right.$ amb) and high $\left(\mathrm{T}^{\mathrm{e}}\right.$ amb $\left.+4^{\circ} \mathrm{C}\right)$ temperature, and control irrigation and drought-stressed GF677 (A) and Adesoto (B) Prunus rootstocks budded with cv. Catherina, after 23 days of treatment.

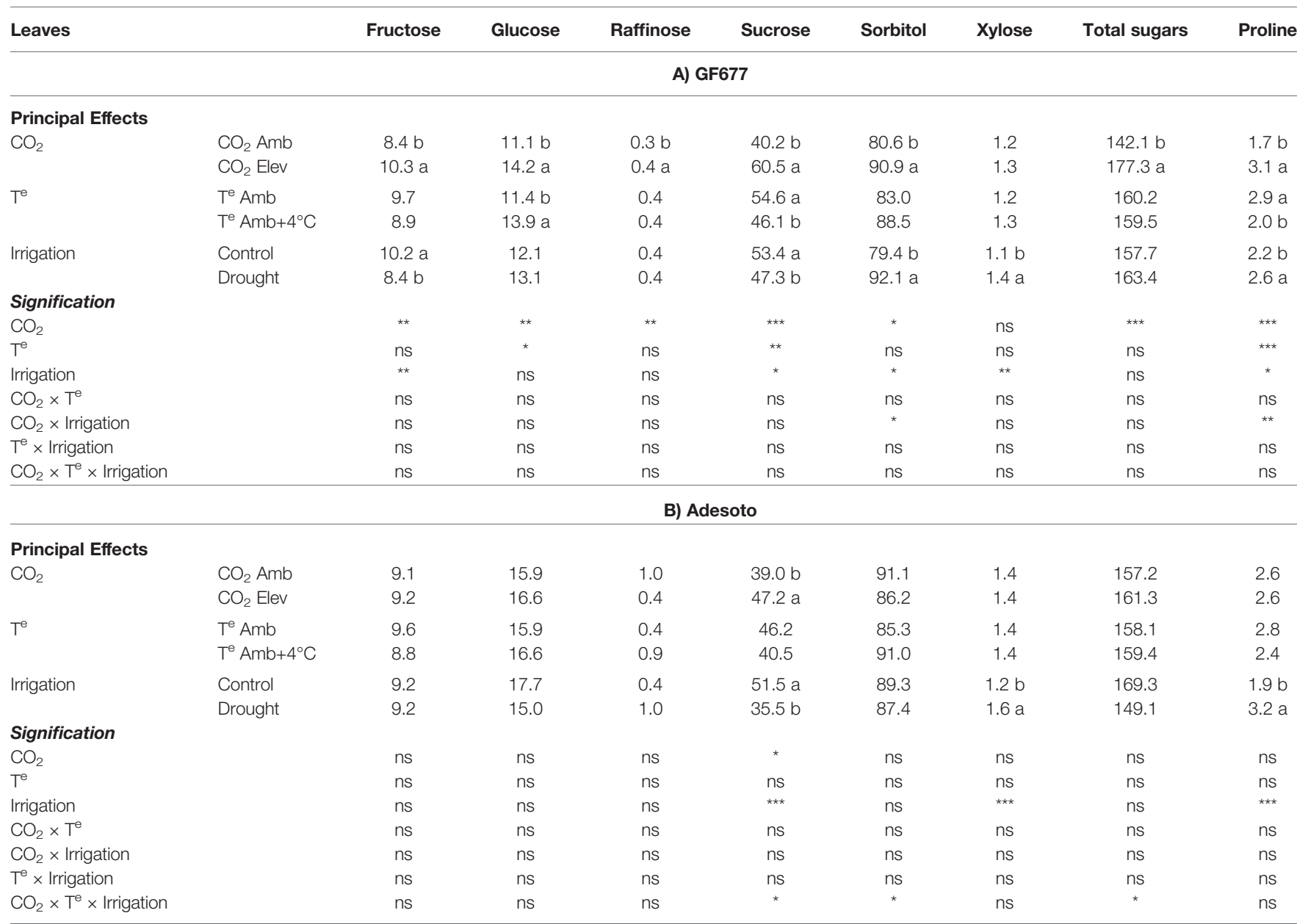

Three-way ANOVA was performed for linear model, on raw data. Significance: ${ }^{*} P \leq 0.05,{ }^{* *} P \leq 0.01,{ }^{* *} P \leq 0.001$ and $n$ s indicates not significant. Comparison means by Duncan's test ( $\left.P \leq 0.05\right)$ were shown for the significant interaction among treatments. Different letters indicate significant differences among data within the same factor. Amb, Ambient; Elev, Elevated; $T^{e}$, Temperature.

increase in proline content in roots of GF677 under drought stress (Table 2A). In roots of the Adesoto rootstock, only four genes were affected by the climate change-like conditions (Table 5B). Elevated $\mathrm{CO}_{2}$ significantly increased the transcript levels of $S 6 P D H$ and $A R E B 2$, while drought condition downregulated the expression of $S D H$. The interactive effect of $\mathrm{CO}_{2}$ and irrigation modified PIP2 gene expression, but without a clear trend (Supplementary Tables 6 and 7). It is important to note that under drought stress, gene regulation of sorbitol metabolism (downregulated catabolism) was consistent with the increase in sorbitol content in roots of Adesoto (Table 2B).

Our results showed that in 'Catherina' scion leaves, elevated $\mathrm{CO}_{2}$ downregulated HAT22 when budded either on GF677 or Adesoto (Table 6). When 'Catherina' was grafted on GF677, drought stress significantly enhanced the expression of S6PDH, SIP1, and HAT22 (Table 6A, Supplementary Table 8). When 'Catherina' was grafted on Adesoto, elevated $\mathrm{CO}_{2}$ and temperature, as well as its interaction, significantly enhanced the expression of $S D H$ in scion leaves (Table 6B, Supplementary Table 9). The transcript level of P5CR decreased in the same rootstock with elevated $\mathrm{CO}_{2}$ and drought stress treatments, but the double and triple interactions did not follow the same trend (Table 6B, Supplementary Table 9). Regarding the ornithine aminotransferase (OAT) gene, which encodes an enzyme that synthesizes a precursor for proline biosynthesis, significant differences in its expression were found only when plants were grafted on Adesoto in the triple interaction, but without a clear trend (Supplementary Table 9). Interestingly, under drought stress conditions, gene regulation related to sorbitol metabolism was consistent with the increase in sorbitol content in scion leaves of GF677 (Table 3A). Furthermore, the lack of accumulation of sorbitol in scion leaves of Adesoto under elevated $\mathrm{CO}_{2}$ and temperature may be due to the upregulation of its catabolism $(S D H)$.

In summary, gene regulation under climate change conditions was divers and depended on the stress, tissue, and genotype (Supplementary Table 10). Concerning tissues, in roots nine different genes associated with specific treatments were modified; eight were affected in GF677, and four in Adesoto. In leaves, five genes were differently expressed on $\mathrm{cv}$. Catherina budded on each rootstock, GF677 or Adesoto. Concerning genotypes, GF677 rootstock showed differences in the expression of 13 genes in both tissues, with roots (eight 
TABLE 4 | Pearson correlations between the physiological traits and biochemical content in leaves and roots of 'Catherina' plants grafted on GF677 and Adesoto rootstocks and subjected to climate change conditions for 23 days $(n=32)$.

\begin{tabular}{|c|c|c|c|c|c|c|c|c|c|c|c|c|c|}
\hline Rootstock & & & Leaves & & & & Rootstock & & & Roots & & & \\
\hline GF677 & Fructose & Sucrose & Xylose & Sorbitol & TSS & Proline & GF677 & Fructose & Glucose & Raffinose & Sorbitol & TSS & Proline \\
\hline$\Psi_{\text {stem }}$ & $0.474^{\star \star}$ & & & & & & & & & $-0.494^{\star \star}$ & $0.524^{* \star}$ & & $-0.585^{\star \star \star}$ \\
\hline$\Psi \pi$ & & $-0.483^{\star \star}$ & & & $-0.507^{\star *}$ & $-0.666^{\star \star \star}$ & & & & & & & \\
\hline RWC & $0.507^{\star \star \star}$ & $0.402^{*}$ & & & & & & & & $-0.505^{\star *}$ & $0.547^{\star \star \star}$ & & $0.583^{\star * *}$ \\
\hline$A_{N}$ & $0.553^{\star \star}$ & $0.679^{\star \star \star}$ & & & & $0.424^{\star}$ & & & & & & & $-0.367^{*}$ \\
\hline$g_{\mathrm{s}}$ & & & & $-0.501^{\star *}$ & & & & & $0.457^{\star}$ & & $0.431^{*}$ & & $-0.394^{*}$ \\
\hline$E$ & & & & $0.493^{\star \star}$ & & & & & & $-0.488^{\star \star}$ & & & $0.584^{\star \star \star}$ \\
\hline WUE & & & & $0.521^{\star \star}$ & $0.515^{\star \star}$ & $0.461^{\star \star}$ & & & $0.727^{\star \star \star}$ & & $-0.379^{*}$ & $0.543^{\star \star}$ & $0.612^{\star \star \star}$ \\
\hline Adesoto & & & Leaves & & & & Adesoto & & & Roots & & & \\
\hline$\Psi_{\text {stem }}$ & & $-0.716^{\star \star \star}$ & $-0.642^{\star \star \star \star}$ & & & $-0.533^{* *}$ & & $0.519^{* *}$ & & & $-0.681^{\star \star \star}$ & & \\
\hline$\Psi \pi$ & & & $-0.460^{* *}$ & & & $-0.391^{\star}$ & & & & & $-0.589^{* \star \star}$ & $-0.507^{* \star}$ & $-0.507^{* *}$ \\
\hline RWC & & & & & & & & & & & & & \\
\hline$A_{N}$ & & $0.610^{\star \star \star}$ & $-0.529^{* *}$ & & & $0.586^{\star \star \star}$ & & $0.601^{\star \star \star}$ & & & $-0.422^{\star}$ & & \\
\hline$g_{\mathrm{s}}$ & & & $-0.455^{\star \star}$ & & & $-0.508^{\star \star}$ & & & & & $-0.429^{\star}$ & & $-0.443^{*}$ \\
\hline$E$ & & $0.576^{\star * \star}$ & $-0.549^{* \star *}$ & & & $0.589^{\star \star \star}$ & & $0.504^{\star \star}$ & & & $-0.447^{\star}$ & & \\
\hline WUE & & & $0.449^{\star}$ & & & & & & & & $0.534^{\star \star}$ & $0.503^{\star \star}$ & $0.474^{\star \star}$ \\
\hline
\end{tabular}

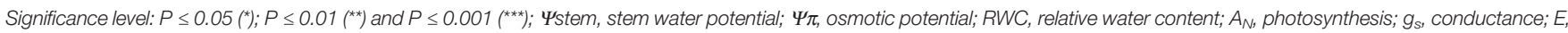
transpiration; WUE, water use efficiency $\left(A_{N} / g_{s}\right)$, TSS, total soluble sugars.

genes) being more affected than scion leaves (five genes). Adesoto rootstock was less affected and only nine genes were modified, four genes in roots and five in scion leaves, respectively. Finally, concerning stresses, in plants grafted on GF677 rootstock, elevated $\mathrm{CO}_{2}$ significantly modified the expression of only two genes, one in each organ tissue, while elevated temperature affected six genes (all in roots), and as a response to the irrigation treatment, seven genes (four in roots, three in leaves) were differentially expressed. Concerning plants grafted on Adesoto rootstock, $\mathrm{CO}_{2}$ treatment altered the expression of five genes (two in roots and three in scion leaves), while elevated temperature (in scion leaves) and irrigation (in roots and scion leaves) modified the expression of only one gene. Elevated temperature did not affect gene expression in leaves of 'Catherina' grafted on GF677 or roots of Adesoto rootstock. The triple interaction between $\mathrm{CO}_{2}$, temperature, and irrigation affected only one gene (SIP1) in 'Catherina' grafted on GF677 rootstock (in leaf tissue) and three genes in the Adesoto-Catherina combination ( $S 6 P D H$ in roots, and $P 5 C R$ and $O A T$ in scion leaves). The double interaction between treatments involved transcriptome variations mainly in leaf tissues.

\section{DISCUSSION}

\section{Effect of Climate Change-Like Conditions (Elevated $\mathrm{CO}_{2}$ and Temperature, and Low Irrigation) on Growth and Physiological Status}

The decrease in shoot/root DW ratio under elevated $\mathrm{CO}_{2}$ and drought suggests that root growth is more stimulated than the aerial part, which was also reported in other plant species (Madhu and Hatfeld, 2013; Medina et al., 2016), although these changes depend on interactions between genotype and environment (Medina et al., 2016). Temperature did not affect biomass as was reported in other plant species (Gray and Brady, 2016). Drought decreased leaf DW and shoot/root ratio in both genotypes, which is in accordance with previous studies in grapevine and wheat (Kizildeniz et al., 2015; Medina et al., 2016) and in Prunus genotypes (Jiménez et al., 2013). Under water deficit, investment in root growth over leaf growth has the benefit of reducing the aerial part avoiding water loss via transpiration (Gray and Brady, 2016). This effect was more evident in plants grafted on the GF677 rootstock that also had increased SPAD values as a consequence of the chlorophyll accumulation. Elevated $\mathrm{CO}_{2}$ alone or in combination with elevated temperature attenuated the negative effect of drought on plant growth in both rootstocks (Fattahi et al., 2019), as was reported previously for elevated $\mathrm{CO}_{2}$ in drought-stressed grapevine plants (Kizildeniz et al., 2015) and in waterlogged cherry rootstocks (Pérez-Jiménez et al., 2018). In the future, climate change conditions may alleviate drought effects in Prunus species, as has been reported for other trees (Kelly et al., 2016).

The photosynthetic rates of plants grafted on GF677 were higher with elevated $\mathrm{CO}_{2}$, but lower with elevated temperature and drought stress. However, the photosynthetic rates of plants grafted on Adesoto decreased only under drought stress conditions. Previous work has shown that elevated $\mathrm{CO}_{2}$ can lead to increases in photosynthetic rates in some plant species, but often involve acclimation process that limit yield and production of biomass. Under such conditions, we found in plants grafted on GF677 an increase in photosynthesis and biomass, while those grafted on Adesoto showed not 
TABLE 5 | Gene expression (Rnorm values) in root tissue $(\mathrm{n}=4)$ under ambient $\left(\mathrm{amb} \mathrm{CO}_{2}\right)$ and high $\left(\mathrm{CO}_{2}\right.$ elev) $\mathrm{CO}_{2}$, ambient $\left(\mathrm{T}^{\mathrm{e}}\right.$ amb) and high $\left(\mathrm{T}^{\mathrm{e}}\right.$ amb $\left.+4^{\circ} \mathrm{C}\right)$ temperature, and control irrigation and drought-stressed GF677 (A) and Adesoto (B) Prunus rootstocks budded with cv. Catherina, after 23 days of treatment.

\begin{tabular}{|c|c|c|c|c|c|c|c|c|c|c|}
\hline Roots & & $S D H$ & S6PDH & SIP1 & P5CS & P5CR & PIP2 & DREB2 & AREB2 & HAT22 \\
\hline \multicolumn{11}{|c|}{ A) GF677 } \\
\hline \multicolumn{11}{|l|}{ Principal Effects } \\
\hline \multirow[t]{2}{*}{$\mathrm{CO}_{2}$} & $\mathrm{CO}_{2} \mathrm{Amb}$ & 9.5 & 0.03 & $1.1 \mathrm{a}$ & 0.5 & 1.8 & 0.1 & 0.4 & 0.2 & 1.4 \\
\hline & $\mathrm{CO}_{2} \mathrm{Elev}$ & 9.1 & 0.01 & $0.9 b$ & 0.7 & 2.1 & 0.1 & 0.3 & 0.2 & 1.7 \\
\hline \multirow[t]{2}{*}{$T^{e}$} & $\mathrm{~T}^{\mathrm{e}} \mathrm{Amb}$ & $13.3 \mathrm{a}$ & $0.03 \mathrm{a}$ & 1.2 & $0.7 \mathrm{a}$ & 2.2 & 0.1 & $0.5 \mathrm{a}$ & $0.2 \mathrm{a}$ & $2.1 \mathrm{a}$ \\
\hline & $\mathrm{T}^{\mathrm{e}} \mathrm{Amb}+4^{\circ} \mathrm{C}$ & $5.3 b$ & $0.01 b$ & 0.7 & $0.5 \mathrm{~b}$ & 1.7 & 0.1 & $0.2 \mathrm{~b}$ & $0.1 \mathrm{~b}$ & $1.0 \mathrm{~b}$ \\
\hline \multirow[t]{2}{*}{ Irrigation } & Control & $14.5 \mathrm{a}$ & $0.01 \mathrm{~b}$ & 0.6 & $0.3 \mathrm{~b}$ & $1.6 \mathrm{~b}$ & 0.1 & 0.4 & 0.2 & 1.7 \\
\hline & Drought & $4.02 \mathrm{~b}$ & $0.03 \mathrm{a}$ & 1.4 & $0.9 \mathrm{a}$ & $2.3 \mathrm{a}$ & 0.1 & 0.4 & 0.2 & 1.3 \\
\hline \multicolumn{11}{|l|}{ Signification } \\
\hline $\mathrm{CO}_{2}$ & & ns & ns & * & ns & ns & ns & ns & $\mathrm{ns}$ & ns \\
\hline $\mathrm{T}^{\mathrm{e}}$ & & 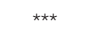 & $\star \star$ & $\mathrm{ns}$ & * & $\mathrm{ns}$ & ns & * & 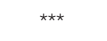 & 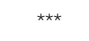 \\
\hline Irrigation & & $* * \star$ & $\star \star$ & ns & $* \star \star *$ & * & ns & ns & ns & ns \\
\hline $\mathrm{CO}_{2} \times \mathrm{T}^{\mathrm{e}}$ & & ns & * & ns & ns & ns & ns & ns & ns & ns \\
\hline $\mathrm{CO}_{2} \times$ Irrigation & & ns & ns & * & ns & ns & ns & ns & * & ns \\
\hline $\mathrm{T}^{\mathrm{e}} \times$ Irrigation & & 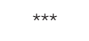 & * & ns & ns & ns & ns & $\mathrm{ns}$ & $\mathrm{ns}$ & ns \\
\hline $\mathrm{CO}_{2} \times \mathrm{T}^{\mathrm{e}} \times$ Irrigation & & ns & ns & ns & ns & ns & ns & ns & ns & ns \\
\hline \multicolumn{11}{|c|}{ B) Adesoto } \\
\hline \multicolumn{11}{|l|}{ Principal Effects } \\
\hline \multirow[t]{2}{*}{$\mathrm{CO}_{2}$} & $\mathrm{CO}_{2} \mathrm{Amb}$ & 7.8 & $0.004 \mathrm{~b}$ & 0.5 & 0.4 & 1.2 & 0.11 & 0.6 & $0.14 b$ & 1.3 \\
\hline & $\mathrm{CO}_{2} \mathrm{Elev}$ & 10.8 & $0.034 \mathrm{a}$ & 0.9 & 0.8 & 1.9 & 0.11 & 0.7 & $0.22 \mathrm{a}$ & 1.8 \\
\hline \multirow[t]{2}{*}{$T^{e}$} & $\mathrm{~T}^{\mathrm{e}} \mathrm{Amb}$ & 10.0 & 0.005 & 0.7 & 0.5 & 1.4 & 0.12 & 0.8 & 0.17 & 1.6 \\
\hline & $\mathrm{T}^{\mathrm{e}} \mathrm{Amb}+4^{\circ} \mathrm{C}$ & 8.6 & 0.032 & 0.7 & 0.7 & 1.8 & 0.10 & 0.5 & 0.19 & 1.5 \\
\hline \multirow[t]{2}{*}{ Irrigation } & Control & $12.8 \mathrm{a}$ & 0.006 & 0.6 & 0.4 & 1.6 & 0.12 & 0.6 & 0.18 & 1.2 \\
\hline & Drought & $5.8 \mathrm{~b}$ & 0.032 & 0.9 & 0.7 & 1.5 & 0.10 & 0.6 & 0.17 & 1.9 \\
\hline \multicolumn{11}{|l|}{ Signification } \\
\hline $\mathrm{CO}_{2}$ & & ns & $\star \star$ & ns & $\mathrm{ns}$ & ns & ns & ns & * & ns \\
\hline $\mathrm{T}^{\mathrm{e}}$ & & ns & ns & ns & ns & ns & ns & ns & ns & ns \\
\hline Irrigation & & $\star \star$ & ns & ns & ns & ns & ns & ns & ns & ns \\
\hline $\mathrm{CO}_{2} \times \mathrm{T}^{\mathrm{e}}$ & & ns & ns & ns & ns & ns & ns & ns & ns & ns \\
\hline $\mathrm{CO}_{2} \times$ Irrigation & & ns & ns & ns & ns & ns & $\star \star$ & ns & ns & ns \\
\hline $\mathrm{T}^{\mathrm{e}} \times$ Irrigation & & ns & ns & ns & ns & ns & ns & ns & ns & ns \\
\hline $\mathrm{CO}_{2} \times \mathrm{T}^{\mathrm{e}} \times$ Irrigation & & ns & * & ns & ns & ns & ns & ns & ns & ns \\
\hline
\end{tabular}

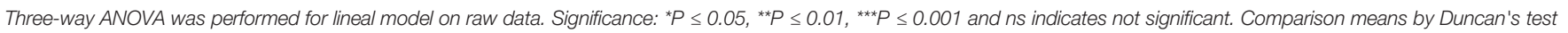
$(P \leq 0.05)$ were shown for the significant interaction among treatments. Different letters indicate significant differences among data within the same factor. Amb, Ambient; Elev, Elevated; $T^{e}$, Temperature.

significant changes. After $23 \mathrm{~d}$ of exposure to elevated $\mathrm{CO}_{2}$, plants grafted on Adesoto rootstock showed acclimation effects irrespective of the temperature and drought stress conditions, as shown in grapevines (Leibar et al., 2015). Leakey et al. (2009) described genetic factors that predispose plants to a greater acclimation of photosynthesis and mentioned the importance of an unbalance in sink capacity leading to increases in foliar carbohydrates. Apparently, this is not the case in the Prunus rootstocks studied herein, because photosynthetic acclimation was not associated with carbohydrate accumulation in scion leaves of GF677 or Adesoto (see sugars leaf/root ratio as fold change in stress compare to control, Figure S1). Differences expressed in a logarithmic basis often allow for easier comparison of preferential compound accumulation in leaves or roots. A positive value $\left[\log _{2}(\right.$ Stress/Control $\left.)>1\right]$ indicates a preferential accumulation in scion leaves under stress conditions. On the contrary, a negative value $\left[\log _{2}\right.$ (Stress/Control) $\left.<1\right]$ indicates preferential accumulation in roots under stress conditions. We found that in GF677-Catherina plants, elevated
$\mathrm{CO}_{2}$ led to increased leaf biomass, decreased SLA, and accumulation of carbohydrates in roots and scion leaves did not provoke acclimation. Similarly, a lack of such acclimation was found in other species as Populus trees that export photosynthates during the day and accumulate the overflow as starch to avoid acclimation, which acts to maintain $A_{\mathrm{N}}$ at elevated $\mathrm{CO}_{2}$ (Scarascia-Mugnozza et al., 2006).

High temperature and drought are frequently co-occurring stresses and they have a substantial impact on the performance and vitality of plants (Afzal et al., 2018). However, at the physiological level, temperature only affected plants grafted on GF677. In these conditions, plants of GF677 showed significantly decreased photosynthesis rates, reduced stomatal conductance, and decreased transpirational water loss, compared to control plants, as reported for grapevine (Leibar et al., 2015). Under drought stress conditions plants grafted on Prunus rootstocks showed a significant decrease in stem and osmotic potentials, photosynthetic rate $\left(A_{\mathrm{N}}\right)$, stomatal conductance $\left(g_{\mathrm{s}}\right)$, and transpiration rate, which is in agreement with previous studies 
TABLE 6 | Gene expression (Rnorm values) in leaf tissue $(\mathrm{n}=4)$ under ambient $\left(\mathrm{amb} \mathrm{CO}_{2}\right)$ and high $\left(\mathrm{CO}_{2}\right.$ elev) $\mathrm{CO}_{2}$, ambient $\left(\mathrm{T}^{\mathrm{e}}\right.$ amb) and high $\left(\mathrm{T}^{\mathrm{e}}\right.$ amb $\left.+4^{\circ} \mathrm{C}\right)$ temperature, and control irrigation and drought-stressed GF677 (A) and Adesoto (B) Prunus rootstocks budded with cv. Catherina, after 23 days of treatment.

\begin{tabular}{|c|c|c|c|c|c|c|c|c|}
\hline Leaves & & SDH & S6PDH & SIP1 & P5CS & P5CR & $O A T$ & HAT22 \\
\hline \multicolumn{9}{|c|}{ A) GF677 } \\
\hline \multicolumn{9}{|l|}{ Principal Effects } \\
\hline $\mathrm{CO}_{2}$ & $\begin{array}{l}\mathrm{CO}_{2} \mathrm{Amb} \\
\mathrm{CO}_{2} \mathrm{Elev}\end{array}$ & $\begin{array}{l}0.3 \\
0.1\end{array}$ & $\begin{array}{l}161.3 \\
178.2\end{array}$ & $\begin{array}{l}5.2 \\
3.0\end{array}$ & $\begin{array}{l}5.5 \\
4.7\end{array}$ & $\begin{array}{l}10.3 \\
5.8\end{array}$ & $\begin{array}{l}32.2 \\
24.3\end{array}$ & $\begin{array}{l}8.3 \mathrm{a} \\
5.0 \mathrm{~b}\end{array}$ \\
\hline $\mathrm{T}^{\mathrm{e}}$ & $\begin{array}{l}\mathrm{T}^{\mathrm{e}} \mathrm{Amb} \\
\mathrm{T}^{\mathrm{e}} \mathrm{Amb}+4^{\circ} \mathrm{C}\end{array}$ & $\begin{array}{l}0.3 \\
0.1\end{array}$ & $\begin{array}{l}219.0 \\
120.5\end{array}$ & $\begin{array}{l}3.9 \\
4.4\end{array}$ & $\begin{array}{l}5.5 \\
4.7\end{array}$ & $\begin{array}{l}6.8 \\
9.3\end{array}$ & $\begin{array}{l}25.5 \\
30.9\end{array}$ & $\begin{array}{l}6.9 \\
6.4\end{array}$ \\
\hline Irrigation & $\begin{array}{l}\text { Control } \\
\text { Drought }\end{array}$ & $\begin{array}{l}0.2 \\
0.2\end{array}$ & $\begin{array}{l}106.7 \mathrm{~b} \\
232.8 \mathrm{a}\end{array}$ & $\begin{array}{l}2.4 \mathrm{~b} \\
5.8 \mathrm{a}\end{array}$ & $\begin{array}{l}4.6 \\
5.7\end{array}$ & $\begin{array}{c}10.3 \\
5.9\end{array}$ & $\begin{array}{l}24.6 \\
31.9\end{array}$ & $\begin{array}{l}5.2 \mathrm{~b} \\
8.2 \mathrm{a}\end{array}$ \\
\hline \multicolumn{9}{|l|}{ Signification } \\
\hline $\mathrm{CO}_{2}$ & & ns & ns & ns & ns & ns & ns & $\star \star$ \\
\hline $\mathrm{T}^{\mathrm{e}}$ & & ns & ns & ns & ns & ns & ns & ns \\
\hline Irrigation & & ns & * & $\star \star$ & ns & ns & ns & * \\
\hline $\mathrm{CO}_{2} \times \mathrm{T}^{\mathrm{e}}$ & & ns & ns & * & * & $\star \star$ & ns & ns \\
\hline $\mathrm{CO}_{2} \times$ Irrigation & & ns & ns & ns & ns & * & ns & * \\
\hline $\mathrm{T}^{\mathrm{e}} \times$ Irrigation & & ns & ns & ns & ns & * & ns & ns \\
\hline $\mathrm{CO}_{2} \times \mathrm{T}^{\mathrm{e}} \times$ Irrigation & & ns & ns & * & ns & ns & ns & ns \\
\hline
\end{tabular}

B) Adesoto

\begin{tabular}{|c|c|c|c|c|c|c|c|c|}
\hline \multicolumn{9}{|l|}{ Principal Effects } \\
\hline \multirow[t]{2}{*}{$\mathrm{CO}_{2}$} & $\mathrm{CO}_{2} \mathrm{Amb}$ & $0.009 \mathrm{~b}$ & 44.1 & 0.8 & 0.9 & $1.9 \mathrm{a}$ & 9.8 & $2.6 \mathrm{a}$ \\
\hline & $\mathrm{CO}_{2}$ Elev & $0.036 \mathrm{a}$ & 34.3 & 0.5 & 0.8 & $1.2 \mathrm{~b}$ & 7.7 & $1.6 \mathrm{~b}$ \\
\hline \multirow[t]{2}{*}{$\mathrm{T}^{\mathrm{e}}$} & $\mathrm{T}^{\mathrm{e}} \mathrm{Amb}$ & $0.009 \mathrm{~b}$ & 46.9 & 0.7 & 0.8 & 1.5 & 8.1 & 1.9 \\
\hline & $\mathrm{T}^{\mathrm{e}} \mathrm{Amb}+4^{\circ} \mathrm{C}$ & $0.036 \mathrm{a}$ & 31.5 & 0.6 & 0.9 & 1.7 & 9.3 & 2.3 \\
\hline \multirow[t]{2}{*}{ Irrigation } & Control & 0.027 & 31.7 & 0.5 & 0.9 & $2.2 \mathrm{a}$ & 9.0 & 1.9 \\
\hline & Drought & 0.018 & 46.7 & 0.9 & 0.7 & $1.0 \mathrm{~b}$ & 8.4 & 2.3 \\
\hline \multicolumn{9}{|l|}{ Signification } \\
\hline $\mathrm{CO}_{2}$ & & * & ns & ns & ns & * & ns & * \\
\hline$T^{e}$ & & $\star$ & ns & ns & ns & ns & ns & ns \\
\hline Irrigation & & ns & ns & ns & ns & $\star \star$ & ns & ns \\
\hline $\mathrm{CO}_{2} \times \mathrm{T}^{\mathrm{e}}$ & & * & ns & ns & * & ns & ns & ns \\
\hline $\mathrm{CO}_{2} \times$ Irrigation & & ns & ns & ns & ns & ns & ns & ns \\
\hline $\mathrm{T}^{\mathrm{e}} \times$ Irrigation & & ns & ns & ns & ns & * & ns & ns \\
\hline $\mathrm{CO}_{2} \times \mathrm{T}^{\mathrm{e}} \times$ Irrigation & & ns & ns & ns & ns & * & * & ns \\
\hline
\end{tabular}

Three-way ANOVA was performed for lineal model on raw data. Significance: ${ }^{*} P \leq 0.05,{ }^{* *} P \leq 0.01$ and ns indicates not significant. Comparison means by Duncan's test ( $\left.\mathrm{P} \leq 0.05\right)$ were shown for the significant interaction among treatments. Different letters indicate significant differences among data within the same factor. Amb, Ambient, Elev, Elevated; $T^{e}$, Temperature.

(Mellisho et al., 2011; Jiménez et al., 2013; Pedroso et al., 2014; Ksouri et al., 2016; Haider et al., 2018). Stomatal closure is one of the earliest responses to water deficiency adopted by plants as a water saving strategy (Long et al., 2006; Serra et al., 2014; Nakhforoosh et al., 2015; Vicente et al., 2015; Pazzagli et al., 2016) to decrease evaporative water loss and maintain a water balance.

In plants grafted on both rootstocks, the combination of climate change-like stress conditions improved water-use efficiency $\left(A_{\mathrm{N} /} g_{\mathrm{s}}\right)$ (Figure 2) except for temperature in Adesoto-Catherina. Also, in both genotypes, the increase in atmospheric $\mathrm{CO}_{2}$ concentration, alone or combined with drought, decreased stomatal conductance and resulted in increases in WUE, as reported for grapevine (Leibar et al., 2015). On the contrary, Centritto and coworkers (Centritto et al., 1999) observed neither reduction of stomatal conductance nor changes in WUE in response to elevated $\mathrm{CO}_{2}$ in droughted cherry plantlets. In this study, elevated $\mathrm{CO}_{2}$ ameliorated the drought-induced decrease in photosynthesis only in plants grafted on GF677.

\section{Metabolic Rearrangements and Transcriptional Regulation in Response to Climate Change-Like Conditions (Elevated $\mathrm{CO}_{2}$ and Temperature, and Low Irrigation)}

Plant growth depends on assimilation of carbohydrates, which are accumulated and mobilized in the form of soluble sugars under stress conditions (Fabbrin et al., 2015; Sami et al., 2016). In this experiment, changes in sugar content in scion leaves and roots under climate stress conditions are summarized as fold changes $[\mathrm{FC}=\log (2)$ (Stress/control)] in Figure S2. Changes (increase or decrease are positive or negative values, respectively) were different between genotypes and among treatments and are related to the biomass changes found in each genotype and tissue combination. The increase in total sugars in roots and leaves in plants grafted on GF677 was consistent with the increase in dry weight in both tissues under elevated $\mathrm{CO}_{2}$ (Figure S2, Table 1). In the same way, increases in fructose, glucose, and total sugars in roots of Adesoto were consistent with the increase in root growth (decrease of shoot/root DW ratio, Table 1). It has been established that metabolic adjustments in response to 
unfavorable conditions are dynamic and multifaceted and not only depend on the type and strength of the stress, but also on the cultivar and the plant species (Krasensky and Jonak, 2012). In this study, elevated $\mathrm{CO}_{2}$ led to an increase in sugars in scion leaves and in roots in GF677 (Figure S2). However, only fructose, raffinose, sucrose, and sorbitol accumulated (Figure S1) more in scion leaves than in roots. Interestingly, in Adesoto soluble sugar concentration, except for sucrose, increased mainly in roots (Figure S2) and accumulated there (Figure S1) being this tissue the main sink. In both genotypes, under elevated $\mathrm{CO}_{2}$, independently of acclimation, the increase and accumulation of sucrose in leaves did not limit photosynthesis neither in plants grafted on GF677 nor Adesoto, which was supported by the positive correlation between sucrose and $A_{\mathrm{N}}$. Furthermore, the increase in proline and its accumulation in leaves of GF677Catherina plants under elevated $\mathrm{CO}_{2}$ may be linked to the role of proline as a ROS scavenger protecting the photosynthetic apparatus from oxidative damage.

Accumulation of particular osmolytes (soluble sugars and/or proline) has been observed in different plant species under stress conditions (Krasensky and Jonak, 2012; Baslam et al., 2014; Fabbrin et al., 2015; Yu et al., 2015; Haider et al., 2017; PérezJiménez et al., 2018) and is thought to help maintain osmolarity. Higher accumulation of compatible solutes may contribute to drought tolerance by protecting the photosynthetic apparatus (Krasensky and Jonak, 2012; Jiménez et al., 2013) and maintaining osmotic homeostasis (Jiménez et al., 2013). In particular, the increases in sorbitol in leaves, raffinose in roots, and proline in both tissues were related to a decrease in osmotic potential and an increase in WUE in Prunus rootstocks (Jiménez et al., 2013). In this study, comparable results were found in GF677 grown under drought stress (increases in raffinose and proline in roots, and sorbitol, xylose, and proline in scion leaves). In the GF677 rootstock under drought stress, sugars accumulated in the same organs, but proline was allocated preferentially in roots. In Adesoto, sorbitol, xylose, and proline increased (Figure S2) and accumulated (Figure S1) under drought stress condition in the same organs, in roots (sorbitol) and in scion leaves (xylose and proline). These changes were also consistent with the negative correlations found between the content of sugar and proline in scion leaves and roots versus stem water and osmotic potentials, indicating a role in maintaining water status in plants grafted on GF677 and Adesoto rootstocks (Table 4). We suggest that the accumulation of sorbitol, xylose, and proline in different plant tissues may increase the tolerance of Prunus trees to progressive drought stress (Figure S1). According to our results, we suggest that proline may act as an osmolyte in roots of GF677 and as a ROS scavenger in leaves of Adesoto-Catherina (partially in GF677) to protect each from oxidative damage (Krasensky and Jonak, 2012). In this regard, each genotype has the capacity to accumulate active solutes as osmolytes and the ability to maintain its own strategy to increase WUE.

Sorbitol is a major end product of photosynthesis that under moderate drought conditions, is preferentially synthesized over sucrose (Escobar-Gutiérrez et al., 1998), which is in agreement with the significant increases in sorbitol content we observed in scion leaves and roots and the decreased sucrose levels in scion leaves in the drought-tolerant GF677. On the contrary, in Adesoto, another pattern was found for sorbitol, which increased only in roots and preferentially accumulated along with sucrose in roots (Figures S1 and S2). Several studies on Prunus rootstocks confirmed that sorbitol content in scion leaves (Ranney et al., 1991; Haider et al., 2018) and in roots (Ranney et al., 1991) were enhanced resulting in active osmotic adjustment and decreased osmotic potential, which increased plant resistance to drought stress (Arndt et al., 2000; Krasensky and Jonak, 2012). Apparently, scion leaf sorbitol in GF677Catherina did not result in osmotic adjustment, while root sorbitol in Adesoto rootstock negatively correlated with osmotic potential (Table 4). Functions of sorbitol-other than osmotic adjustment-such as translocation and storage of carbon, cryoprotection, and prevention of reactive oxygen species, have been described previously (Lo Bianco et al., 2000). The osmotic adjustment of sorbitol in roots may influence shoot/root partitioning patterns and root growth, and may indirectly control plant growth in responses to water deficit (Turner, 1986). We may speculate that the allocation of sorbitol in roots of Adesoto may be a stimulus to increase the photosynthetic rate and evade or reduce the acclimation process.

In order to shed light on the complex regulatory networks of all changes at the molecular level caused by climate change-like stress conditions, we followed the expression of genes that regulate sugar and proline metabolism. Sorbitol levels were determined by the balance between biosynthesis and catabolism. Sorbitol is synthesized by S6PDH (sorbitol-6phosphate dehydrogenase) in source leaves, translocated through phloem, and catabolized by SDH in fruit (Suzuki and Dandekar, 2014) and other sink organs. As a result of drought stress, the increase in sorbitol content in scion leaves of GF677 was consistent with the upregulation of $S 6 P D H$ as found previously in peach leaves (Sakanishi et al., 1998). However under climate change-like stress conditions, SDH transcript levels were not correlated with sorbitol content, suggesting that other factors have significant regulatory effects, as other authors have pointed out under control conditions (Wu et al., 2010). Likewise, the enhanced expression of SIP1 in scion leaves of GF677 under drought stress did not provide evidence supporting a role of raffinose in stress tolerance as was reported in Prunus rootstocks (Jiménez et al., 2013) or in Arabidopsis plants (Krasensky and Jonak, 2012).

Proline is biosynthesized in plants through two successive reductions catalyzed by 1-pyrroline-5-carboxylate synthetase and pyrroline-5-carboxylate reductase (Verbruggen and Hermans, 2008). In the present study, the significant increases in P5CS and P5CR under drought stress were accompanied by higher proline content in roots of the tolerant rootstock GF677 as it was found in P5CS in GF677 and Cadaman rootstocks (Jiménez et al., 2013). However, in leaves of 'Catherina' grafted on Adesoto, we found the opposite. P5CR was downregulated while proline content increased under drought stress without evidences that confirmed the synthesis of proline precursor through the ornithine alternative pathway (Miller et al., 2009). 
The apparent inconsistency for the downregulation of P5CR under elevated $\mathrm{CO}_{2}$ and drought treatments and the increase of proline in scion leaves of Adesoto could be explained by gene regulation linked to the interaction. In line with the contrasting results found in both genotypes in this study, Szabados and Savoure (2010) reported that the correlation between proline content and abiotic stress in plants is not always positive and may be genotype-dependent.

Finally, to better establish differences among stresses and to understand the regulation of the physiological and molecular responses found among the genotypes, we explored gene expression of stress-inducible and -responsive genes. It has been described that many stress-inducible genes are enriched in motifs that are binding targets of transcription factors (drought or ABAregulated genes) (Huang et al., 2008). Numerous gene families and transcription factors (TFs) are implicated in the defense responses to stress in plants through regulation of metabolites levels. DREB2, which encodes a DRE/CRT-binding protein, activates the expression of genes related to osmoprotectant and antioxidant biosynthesis and whose expression is rapidly induced by osmotic stress (Song et al., 2014). However, our results are in contrast with the upregulation found under high temperature in poplar (Song et al., 2014) and under drought stress in peach leaves (Haider et al., 2018). In our experimental conditions, the lack of activation of DREB2 could be due to elevated temperature or drought stress in Prunus rootstocks not related to oxidative damage as found in Arabidopsis (Hwang et al., 2012). Furthermore, AREB encodes a major TF involved in abiotic stress responses in Arabidopsis (Fujita et al., 2013; Nakashima et al., 2014). Overexpression of $A R E B 1$ in rice and soybean improved drought tolerance (Oh et al., 2005), while overexpression of $A R E B 2$ in apple led to increased sugar accumulation ( $\mathrm{Ma}$ et al., 2017). In our study, the downregulation of $A R E B$ in roots of GF677 under elevated temperature may be linked to the lack of significant accumulation of sugars in this organ. On the contrary, upregulation of $A R E B$ in roots of Adesoto under elevated $\mathrm{CO}_{2}$ treatment may be linked to the accumulation of total sugars (Figure S1). Finally, the homeodomain-leucine zipper (HDZPII) gene (HAT22) was upregulated in scion leaves of GF677 under drought stress conditions, as was found previously in cotton plants as a response to drought stress (Hou et al., 2018) and in Arabidopsis in response to ABA treatment and drought (Liu et al., 2016). It has been reported that the dehydration-responsive homeodomain-leucine zipper gene family (HD-Zips) show modulated expression in response to dehydration in leaves and roots (Deng et al., 2002), supporting the role of HD-Zips in regulatory pathways that lead to desiccation tolerance. Results found in plants grafted on GF677 may be in agreement with the model proposed in Arabidopsis (Liu et al., 2016) concerning the role of HAT22/ABIG1 TF. In this combination, drought may act through ABA to increase HAT22 transcription to limit shoot growth and promote leaf senescence. In contrast, in AdesotoCatherina the response concerning shoot growth and senescence was less evident.

Taken into account all these transcriptomic changes, it underscores the difficulty in understanding the global context of multi-stress responses. The broad number of genes that are differentially modified under environmental stress conditions reveals the complex regulatory network of TFs controlling plant responses at the morphological, physiological, and molecular level.

\section{CONCLUSION}

Climate change will alter future plant growth conditions and, in this scenario, knowledge of the plasticity of Prunus rootstocks will be critical for peach production. Elevated $\mathrm{CO}_{2}$, elevated temperature, and drought stress were applied to simulate future climate conditions and to compare two contrasting Prunus rootstocks for 'Catherina' peach at the physiological, molecular, and transcriptomic level. This study revealed that the impact of climate change was not uniform for Prunus species and the responses depend on the genetic background and the performance of the genotypes facing the stress in a specific manner.

In response to stress, morphological and physiological changes were accompanied by molecular and transcriptomic changes in a coordinated manner, but depending on the rootstock. Elevated $\mathrm{CO}_{2}$ increased photosynthetic rates in plants grafted on GF677, while in plants grafted in Adesoto, acclimation was observed. At the molecular level, metabolite content was affected by climate change-like stress factors such that soluble sugars and proline were partitioned in different shoot:root patterns depending on the stress and the genotype. Under elevated $\mathrm{CO}_{2}$, osmoprotectants accumulated in leaves of GF677-Catherina, while in Adesoto-Catherina these metabolites accumulated mainly in roots. The metabolic adjustments developed in response to stress involved pathways controlling levels of sugar and proline that were highly coordinated and regulated at the transcriptomic level $(S D H, S 6 P D H, S I P 1, P 5 C R$, and P5CS) in both tissues and genotypes.

Stress tolerance is a complex trait that is controlled by multiple genes. GF677-grafted plants showed more changes than those grafted on Adesoto, scion leaves were more affected than roots, although some responses were quite similar for both genotypes and varied depending on the stress and the affected tissue. We conclude that both peach rootstocks may be tolerant to climate change, but the strategies employed by each genotype in response to stress are different and are associated with the genetic background.

GF677 is a tolerant rootstock that utilizes a range of machinery to maintain good performance, and control plant growth and senescence under stress. At elevated $\mathrm{CO}_{2}$, plants increase $A_{\mathrm{N}}$, and as a consequence, the rootstock needs to control oxidative stress and plant growth. This genotype increased proline content in scion leaves as a ROS scavenger and downregulated HAT22 to avoid senescence and increase leaf growth, to create a better balance with root growth. At elevated temperature, no significant changes were found in growth, but all transcriptomic changes were in roots to control root growth and senescence via downregulation of genes (AREB2 to reduce the accumulation of sugars and HAT22 to restrict growth and senescence). Under drought stress, this rootstock controls leaf 
growth via the upregulation of HAT22, which may result in a decrease in aerial growth in favor of root growth to improve water uptake. Adesoto is a resilient rootstock suitable to grow under climate change stress conditions. Under elevated $\mathrm{CO}_{2}$, this rootstock is able to control photosynthesis, growth, and sugar biosynthesis. It is also insensitive to elevated temperature, and under drought stress, maintains water status through metabolic balance among tissues. In scion leaves, HAT22 was downregulated maintaining growth of the aerial part. In roots, $A R E B 2$ was upregulated to promote accumulation of sugars and indirectly stimulate photosynthesis. This study confirms the importance of rootstocks in sensing stress, regulating of scion growth, and conferring tolerance to the variety. This work establishes a basis for developing screening methods that may enable early selection of woody tree species adapted to new environmental scenarios.

\section{DATA AVAILABILITY STATEMENT}

All datasets generated for this study are included in the article/ Supplementary Material.

\section{AUTHOR CONTRIBUTIONS}

SJ and YG devised the study objectives and designed the experiment. SJ carried out the experiment, conducted the statistical analysis and drafted the manuscript. MF contributed to the writing of the paper, to the statistical analysis and figure preparation. $\mathrm{KB}$ conducted the expression analysis work. SN-m contributed to the writing. JJI helped with the experimental facilities and physiological measures and supervised the manuscript. YG

\section{REFERENCES}

Ábrahám, E., Hourton-Cabassa, C., Erdei, L., and Szabados, L. (2010). Methods for determination of proline in plants. Methods Mol. Biol. 639, 317-331. doi: 10.1007/978-1-60761-702-0_20

Afzal, M., Shabbir, G., Ilyas, M., Jan, S.S.A., and Jan, S. A. (2018). Impact of climate change on crop adaptation: current challenges and future perspectives. Pure Appl. Biol. 7, 965-972. doi: 10.19045/bspab.2018.700115

Ainsworth, E. A., Leakey, A. D. B., Ort, D. R., and Long, S. P. (2008). FACE-ing the facts: inconsistencies and interdependence among field, chamber and modeling studies of elevated $\mathrm{CO}_{2}$ impacts on crop yield and food supply. New Phytol. 179, 5-9. doi: 10.1111/j.1469-8137.2008.02500.x

Aranjuelo, I., Irigoyen, J. J., Perez, P., Martinez-Carrasco, R., and Sanchez-Díaz, M. (2005). The use of temperature gradient tunnels for studying the combined effect of $\mathrm{CO}_{2}$, temperature and water availability in $\mathrm{N}_{2}$ fixing alfalfa plants. Ann. Appl. Biol. 146, 51-60. doi: 10.1111/j.1744-7348.2005.04074.x

Aranjuelo, I., Irigoyen, J. J., Perez, P., Martinez-Carrasco, R., and Sanchez-Diaz, M. (2006). Response of nodulated alfalfa to water supply, temperature and elevated $\mathrm{CO}_{2}$ : Productivity and water relations. Environ. Exp. Bot. 55, 130141. doi: 10.1016/j.envexpbot.2004.10.007

Aranjuelo, I., Cabrera-Bosquet, L., Morcuende, R., Avice, J. C., Nogués, S., Araus, J. L., et al. (2011). Does ear C sink strength contribute to overcoming photosynthetic acclimation of wheat plants exposed to elevated $\mathrm{CO}_{2}$ ? J. Exp. Bot. 62, 3957-3969. doi: 10.1093/jxb/err095

Arndt, S. K., Wanek, W., Clifford, S. C., and Popp, M. (2000). Contrasting adaptations to drought stress in field-grown Ziziphus mauritiana and conceived the experiment, wrote and edited the paper and helped with the statistical analysis. All authors read and approved the manuscript.

\section{FUNDING}

This work was partly funded by the Spanish Ministry of Economy and Competitiveness grants AGL2014-52063R, AGL2017-83358-R (MCIU/AEI/FEDER/UE); and the Government of Aragón with grants A44, A09_17R and La Caixa-GA-0007/2010 which were co-financed with FEDER funds. MF and SN-M were recipients of Iranian fellowships. SJ was supported by JAE-Doc-CSIC contract co-funded by ESF. KB received a Master's fellowship awarded by the CIHEAM-IAMZ.

\section{ACKNOWLEDGMENTS}

We thank M. Sánchez-Díaz and the Universidad de Navarra for allowing us to use the apparatus and all the TGGs facilities. We also thank V. Barja, D. Gutiérrez, J. Dridi, A. Urdiain, J. Montenegro for the excellent technical assistance and J. Pinochet (Agromillora Iberia S.L.) and M.A. Moreno (EEADCSIC) for providing the plant material.

\section{SUPPLEMENTARY MATERIAL}

The Supplementary Material for this article can be found online at: https://www.frontiersin.org/articles/10.3389/fpls.2020.00043/ full\#supplementary-material

Prunus persica trees: water relations, osmotic adjustment and carbon isotope composition. Aust. J. Grape Wine Res. 27, 985-996. doi: 10.1071/PP00022

Arp, W. (1991). Effects of source-sink relations on photosynthetic acclimation to elevated $\mathrm{CO}_{2}$. Plant Cell Environ. 14, 869-875. doi: 10.1111/j.13653040.1991.tb01450.x

Baslam, M., Antolín, M. C., Gogorcena, Y., Muñoz, F., and Goicoechea, N. (2014). Changes in alfalfa forage quality and stem carbohydrates induced by arbuscular mycorrhizal fungi and elevated atmospheric $\mathrm{CO}_{2}$. Ann. Appl. Biol. 164, 190199. doi: 10.1111/aab.12092

Bates, L. S., Waldren, R. P., and Teare, I. D. (1973). Rapid determination of free proline for water-stress studies. Plant Soil 39, 205-207. doi: 10.1007/BF00018060

Bencze, S., Bamberger, Z., Janda, T., Balla, K., Varga, B., Bedö, Z., et al. (2014). Physiological response of wheat varieties to elevated atmospheric $\mathrm{CO}_{2}$ and low water supply levels. Photosynthetica 52, 71-82. doi: 10.1007/s11099014-0008-y

Cattivelli, L., Rizza, F., Badeck, F., Mazzucotelli, E., Mastrangelo, A. M., Francia, E., et al. (2008). Drought tolerance improvement in crop plants: an integrated view from breeding to genomics. Field Crops Res. 105, 1-14. doi: 10.1016/ j.fcr.2007.07.004

Centritto, M., Lee, H., and Jarvis, P. (1999). Interactive effects of elevated $\left[\mathrm{CO}_{2}\right]$ and drought on cherry (Prunus avium) seedlings. New Phytol. 141, 129-140. doi: 10.1046/j.1469-8137.1999.00327.x

Deng, X., Phillips, J., Meijer, A. H., Salamini, F., and Bartels, D. (2002). Characterization of five novel dehydration-responsive homeodomain leucine zipper genes from the resurrection plant Craterostigma plantagineum. Plant Mol. Biol. 49, 601-610. doi: 10.1023/A:1015501205303 
Erice, G., Sanz-Sáez, A., Urdiain, A., Araus, J. L., Irigoyen, J. J., and Aranjuelo, I. (2014). Harvest index combined with impaired $\mathrm{N}$ availability constrains the responsiveness of durum wheat to elevated $\mathrm{CO}_{2}$ concentration and terminal water stress. Funct. Plant Biol. 41, 1138-1147. doi: 10.1071/FP14045

Escobar-Gutiérrez, A., Zipperlin, B., Carbonne, F., Moing, A., and Gaudillere, J. (1998). Photosynthesis, carbon partitioning and metabolite content during drought stress in peach seedlings. Aust. J. Plant Physiol. 25, 197-205. doi: 10.1071/PP97121

Fabbrin, E. G., Gogorcena, Y., Mogor, A. F., Garmendia, I., and Goicoechea, N. (2015). Pearl millet growth and biochemical alterations determined by mycorrhizal inoculation, water availability and atmospheric $\mathrm{CO}_{2}$ concentration. Crop Pasture Sci. 66, 831-840. doi: 10.1071/CP14089

FAO (2016). The State of Food and Agriculture: Climate Change, Agriculture and Food Security (Rome: Food and Agriculture Organization of the United Nations).

Fathi, H., Amiri, M. E., Imani, A., Hajilou, J., and Nikbakht, J. (2017). Response of almond genotypes/cultivars grafted on GN15 "Garnem" rootstock in deficitirrigation stress conditions. J. Nuts 8, 123-135. doi: 10.22034/jon.2017.536243

Fattahi, M., Jiménez, S., Nasrolahpour-moghadam, S., Irigoyen, J., and Gogorcena, Y. (2019). "Effects of climate change on peach grafted into two contrasting Prunus spp. rootstocks," in XXIII of the Spanish Society of Plant Physiology (Pamplona (Spain): Spanish Society of Plant Physiology), 89.

Fujita, Y., Yoshida, T., and Yamaguchi-Shinozaki, K. (2013). Pivotal role of the AREB/ABF-SnRK2 pathway in ABRE-mediated transcription in response to osmotic stress in plants. Physiol. Plant 147, 15-27. doi: 10.1111/j.13993054.2012.01635.x

García-Sánchez, F., Syvertsen, J. P., Gimeno, V., Botía, P., and Perez-Perez, J. G. (2007). Responses to flooding and drought stress by two citrus rootstock seedlings with different water-use efficiency. Physiol. Plant 130, 532-542. doi: 10.1111/j.13993054.2007.00925.x

Gogorcena, Y., Iturbe-Ormaetxe, I., Escuredo, P. R., and Becana, M. (1995). Antioxidant defenses against activated oxygen in pea nodules subjected to water stress. Plant Physiol. 108, 753-759. doi: 10.1104/pp.108.2.753

Gogorcena, Y., Sánchez, G., Moreno, S., Pérez, S., and Ksouri, N. (2020). "Genomic-based breeding for climate-smart peach varieties," in Genome designing of climate fruit crops. Ed. Ch. Kole (Cham, Switzerland AG: Springer Nature). 291-351. doi: 10.1007/978-3-319-97946-5_9

Gray, S. B., and Brady, S. M. (2016). Plant developmental responses to climate change. Dev. Biol. 419, 64-77. doi: 10.1016/j.ydbio.2016.07.023

Haider, M. S., Zhang, C., Kurjogi, M. M., Pervaiz, T., Zheng, T., Zhang, C., et al. (2017). Insights into grapevine defense response against drought as revealed by biochemical, physiological and RNA-Seq analysis. Sci. Rep. 7, 1-15. doi: 10.1038/ s41598-017-13464-3

Haider, M. S., Kurjogi, M. M., Khalil-ur-Rehman, M., Pervez, T., Songtao, J., Fiaz, M., et al. (2018). Drought stress revealed physiological, biochemical and geneexpressional variations in 'Yoshihime' peach (Prunus persica L) cultivar. J. Plant Interact. 13, 83-90. doi: 10.1080/17429145.2018.1432772

Hou, S., Zhu, G., Li, Y., Li, W., Fu, J., Niu, E., et al. (2018). Genome-wide association studies reveal genetic variation and candidate genes of drought stress related traits in cotton (Gossypium hirsutum L.). Front. Plant Sci. 9, 1-15. doi: 10.3389/ fpls.2018.01276

Huang, D., Wu, W., Abrams, S. R., and Cutler, A. J. (2008). The relationship of drought-related gene expression in Arabidopsis thaliana to hormonal and environmental factors. J. Exp. Bot. 59, 2991-3007. doi: 10.1093/jxb/ern155

Hwang, J., Lim, C., Chen, H., Je, J., Song, C., and Lim, C. (2012). Overexpression of Arabidopsis dehydration-responsive element-binding protein $2 \mathrm{C}$ confers tolerance to oxidative stress. Mol. Cells 33, 135-140. doi: 10.1007/s10059-012-2188-2

Iacono, F., Buccella, A., and Peterlunger, E. (1998). Water stress and rootstock influence on leaf gas exchange of grafted and ungrafted grapevines. Sci. Hortic. (Amsterdam). 75, 27-39. doi: 10.1016/S0304-4238(98)00113-7

IPCC (2014). "Climate Change 2014 Synthesis Report," in Contribution of Working Groups I, II and III to the Fifth Assessment Report of the Intergovernmental Panel on Climate Change. Eds. R. K. Pachauri and L. A. Meyer Geneva (Switzerland: Intergovernmental Panel on Climate Change (IPCC)).

IPCC (2018). "Global warming of $1.5^{\circ} \mathrm{C}$," in An IPCC Special Report on the impacts of global warming of $1.5^{\circ} \mathrm{C}$ above pre-industrial levels and related global greenhouse gas emission pathways, in the context of strengthening the global response to the threat of climate change, sustainable development. Intergovernmental Panel on Climate Change (IPCC). T. W. V. Masson-Delmotte, P. Zhai, H. O. PörtnerV. MassonDelmotte, P. Zhai, H. O. Pörtner, D. Roberts, J. Skea, P. R. Shukla, A. Pirani, W. Moufouma-Okia, C. Péan, R. Pidcock, S. Connors, J. B. R. Matthews, Y. Chen, X. Zhou, M. I. Gomis, E. Lonnoy and T. Maycock

Irigoyen, J. J., Goicoechea, N., Antolín, M. C., Pascual, I., Sánchez-Díaz, M., Aguirreolea, J., et al. (2014). Growth, photosynthetic acclimation and yield quality in legumes under climate change simulations : an updated survey. Plant Sci. 226, 22-29. doi: 10.1016/j.plantsci.2014.05.008

Jiménez, S., Dridi, J., Gutiérrez, D., Moret, D., Irigoyen, J. J., Moreno, M. A., et al. (2013). Physiological, biochemical and molecular responses in four Prunus rootstocks submitted to drought stress. Tree Physiol. 33, 1061-1075. doi: $10.1093 /$ treephys/tpt074

Jones, H. G. (2007). Monitoring plant and soil water status: Established and novel methods revisited and their relevance to studies of drought tolerance. J. Exp. Bot. 58, 119-130. doi: 10.1093/jxb/erl118

Kelly, J. W. G., Duursma, R. A., Atwell, B. J., Tissue, D. T., and Medlyn, B. E. (2016). Drought $\times \mathrm{CO}_{2}$ interactions in trees: a test of the low-intercellular $\mathrm{CO}_{2}$ concentration (Ci) mechanism. New Phytol. 209, 1600-1612. doi: 10.1111/ nph. 13715

Kizildeniz, T., Mekni, I., Santesteban, H., Pascual, I., Morales, F., and Irigoyen, J. J. (2015). Effects of climate change including elevated $\mathrm{CO}_{2}$ concentration, temperature and water deficit on growth, water status, and yield quality of grapevine (Vitis vinifera L.) cultivars. Agric. Water Manage. 159, 155-164. doi: 10.1016/j.agwat.2015.06.015

Kizildeniz, T., Pascual, I., Irigoyen, J. J., and Morales, F. (2018). Using fruit-bearing cuttings of grapevine and temperature gradient greenhouses to evaluate effects of climate change (elevated $\mathrm{CO}_{2}$ and temperature, and water deficit) on the cv. red and white Tempranillo. Yield and must quality in three consecutive growin. Agric. Water Manage. 202, 299-310. doi: 10.1016/j.agwat.2017.12.001

Krasensky, J., and Jonak, C. (2012). Drought, salt, and temperature stress-induced metabolic rearrangements and regulatory networks. J. Exp. Bot. 63, 1593-1608. doi: $10.1093 / \mathrm{jxb} / \mathrm{err} 460$

Ksouri, N., Jiménez, S., Wells, C. E., Contreras-Moreira, B., and Gogorcena, Y. (2016). Transcriptional responses in root and leaf of Prunus persica under drought stress using RNA sequencing. Front. Plant Sci. 7, 1715. doi: 10.3389/ fpls.2016.01715

Leakey, A. D. B., Ainsworth, E. A., Bernacchi, C. J., Rogers, A., Long, S. P., and Ort, D. R. (2009). Elevated $\mathrm{CO}_{2}$ effects on plant carbon, nitrogen, and water relations: Six important lessons from FACE. J. Exp. Bot. 60, 2859-2876. doi: $10.1093 / \mathrm{jxb} / \mathrm{erp} 096$

Leibar, U., Aizpurua, A., Unamunzaga, O., Pascual, I., and Morales, F. (2015). How will climate change influence grapevine $\mathrm{cv}$. Tempranillo photosynthesis under different soil textures? Photosynth. Res. 124, 199-215. doi: 10.1007/s11120-015-0120-2

Liu, T., Longhurst, A. D., Talavera-Rauh, F., Hokin, S. A., and Barton, M. K. (2016). The Arabidopsis transcription factor ABIG1 relays ABA signaled growth inhibition and drought induced senescence. Elife 5, 1-19. doi: 10.7554/eLife.13768

Lo Bianco, R., Rieger, M., and Sung, S. J. S. (2000). Effect of drought on sorbitol and sucrose metabolism in sinks and sources of peach. Physiol. Plant 108, 71-78. doi: 10.1034/j.1399-3054.2000.108001071.x

Long, S. P., Ainsworth, E. A., Rogers, A., and Ort, D. R. (2004). Rising atmospheric carbon dioxide: Plants FACE the future. Annu. Rev. Plant Biol. 55, 591-628. doi: 10.1146/annurev.arplant.55.031903.141610

Long, S. P., Ainsworth, E. A., Leakey, A. D. B., Nösberger, J., and Ort, D. R. (2006). Food for thought: lower-than-expected crop yield stimulation with rising $\mathrm{CO}_{2}$ concentrations. Science (80-.), 1918-1921. doi: 10.1126/ science. 1114722

Lovisolo, C., Perrone, I., Carra, A., Ferrandino, A., Flexas, J., Medrano, H., et al. (2010). Drought-induced changes in development and function of grapevine (Vitis spp.) organs and in their hydraulic and non-hydraulic interactions at the whole-plant level: a physiological and molecular update. Funct. Plant Biol. 37, 98. doi: 10.1071/FP09191

Ma, Q. J., Sun, M. H., Lu, J., Liu, Y. J., Hu, D. G., and Hao, Y. J. (2017). Transcription factor AREB2 is involved in soluble sugar accumulation by activating sugar transporter and amylase genes. Plant Physiol. 174, 2348-2362. doi: $10.1104 /$ pp.17.00502 
Madhu, M., and Hatfeld, J. L. (2013). Dynamics of plant root growth under increased atmospheric carbon dioxide. Agron. J. 105, 657-669. doi: 10.2134/ agronj2013.0018

Martínez-Lüscher, J., Kizildeniz, T., Vučetić, V., Dai, Z., Luedeling, E., van Leeuwen, C., et al. (2016). Sensitivity of grapevine phenology to water availability, temperature and $\mathrm{CO}_{2}$ concentration. Front. Environ. Sci. 4, 48. doi: $10.3389 /$ fenvs. 2016.00048

Medina, S., Vicente, R., Amador, A., and Araus, J. L. (2016). Interactive effects of elevated $\left[\mathrm{CO}_{2}\right]$ and water stress on physiological traits and gene expression during vegetative growth in four durum wheat genotypes. Front. Plant Sci. 7, 1-17. doi: $10.3389 /$ fpls.2016.01738

Meggio, F., Prinsi, B., Negri, A., Simone di Lorenzo, G., Lucchini, G., Pitacco, A., et al. (2014). Biochemical and physiological responses of two grapevine rootstock genotypes to drought and salt treatments. Aust. J. Grape Wine Res. 20, 310-323. doi: 10.1111/ajgw.12071

Meisel, L., Fonseca, B., Gonzalez, S., Baeza-Yates, R., Cambiazo, V., Campos, R., et al. (2005). A rapid and efficient method for purifying high quality total RNA from peaches (Prunus persica) for functional genomics analyses. Biol. Res. 38, 83-88. doi: 10.4067/S0716-97602005000100010

Mellisho, C. D., Cruz, Z. N., Conejero, W., Ortuno, M. F., and Rodríguez, P. (2011). Mechanisms for drought resistance in early maturing cvar Flordastar peach trees. J. Agric. Sci. 149, 609-616. doi: 10.1017/S0021859611000141

Miller, G., Honig, A., Stein, H., Suzuki, N., Mittler, R., and Zilberstein, A. (2009). Unraveling delta1-pyrroline-5- carboxylate-proline cycle in plants by uncoupled expression of proline oxidation enzymes. J. Biol. Chem. 284, 26482-26492. doi: 10.1074/jbc.M109.009340

Moing, A., Maucourt, M., Renaud, C., Gaudillère, M., Brouquisse, R., Lebouteiller, B., et al. (2004). Quantitative metabolic profiling by 1-dimensional $1 \mathrm{H}-\mathrm{NMR}$ analyses: application to plant genetics and functional genomics. Funct. Plant Biol. 31, 889-902. doi: 10.1071/FP04066

Morales, F., Pascual, I., Sánchez-Díaz, M., Aguirreolea, J., Irigoyen, J. J., Goicoechea, N., et al. (2014). Methodological advances: Using greenhouses to simulate climate change scenarios. Plant Sci. 226, 30-40. doi: 10.1016/j.plantsci.2014.03.018

Morgan, J. (1984). Osmoregulation and water stress in higher plants. Annu. Rev. Plant Physiol. 35, 299-319. doi: 10.1146/annurev.pp.35.060184.001503

Nakashima, K., Yamaguchi-Shinozaki, K., and Shinozaki, K. (2014). The transcriptional regulatory network in the drought response and its crosstalk in abiotic stress responses including drought, cold, and heat. Front. Plant Sci. 5, 1-7. doi: $10.3389 /$ fpls. 2014.00170

Nakhforoosh, A., Grausgruber, H., Kaul, H. P., and Bodner, G. (2015). Dissection of drought response of modern and underutilized wheat varieties according to passioura's yield-water framework. Front. Plant Sci. 6, 1-13. doi: 10.3389/ fpls.2015.00570

NOAA Mauna Loa Atmospheric Baseline Observatory (2019). Carbon dioxide levels hit record peak in May. Available at: https://research.noaa.gov/article/ ArtMID/587/ArticleID/2461/Carbon-dioxide-levels-hit-record-peak-in-May.

Oh, S.-J., Song, S. I., Kim, Y. S., Jang, H.-J., Kim, S. Y., Kim, M., et al. (2005). Arabidopsis $\mathrm{CBF} 3 / \mathrm{DREB} 1 \mathrm{~A}$ and $\mathrm{ABF} 3$ in transgenic rice increased tolerance to abiotic stress without stunting growth. Plant Physiol. 138, 341-351. doi: 10.1104/pp.104.059147

Pérez-Jiménez, M., Hernández-Munuera, M., Piñero, M. C., López-Ortega, G., and del Amor, F. M. (2018). Are commercial sweet cherry rootstocks adapted to climate change? Short-term waterlogging and $\mathrm{CO}_{2}$ effects on sweet cherry cv. 'Burlat.'. Plant Cell Environ. 41, 908-918. doi: 10.1111/pce.12920

Pazzagli, P. T., Weiner, J., and Liu, F. (2016). Effects of $\mathrm{CO}_{2}$ elevation and irrigation regimes on leaf gas exchange, plant water relations, and water use efficiency of two tomato cultivars. Agric. Water Manage. 169, 26-33. doi: 10.1016/ j.agwat.2016.02.015

Pedroso, F. K. J. V., Prudente, D. A., Bueno, A. C. R., Machado, E. C., and Ribeiro, R. V. (2014). Drought tolerance in citrus trees is enhanced by rootstockdependent changes in root growth and carbohydrate availability. Environ. Exp. Bot. 101, 26-35. doi: 10.1016/j.envexpbot.2013.12.024

Ranney, T. G., Bassuk, N. L., and Whitlow, T. H. (1991). Osmotic adjustment and solute constituents in leaves and roots of water-stressed cherry (Prunus) trees. J. Am. Soc Hortic. Sci. 116, 684-688. doi: 10.21273/JASHS.116.4.684

Ruijter, J. M., Ramakers, C., Hoogaars, W. M. H., Karlen, Y., Bakker, O., Van den Hoff, M. J. B., et al. (2009). Amplification efficiency: linking baseline and bias in the analysis of quantitative PCR data. Nucleic Acids Res. 37, e45. doi: 10.1093/nar/ gkp045

Sakanishi, K., Kanayama, Y., Mori, H., Yamada, K., and Yamaki, S. (1998). Expression of the gene for NADH-dependent sorbitol-6-phosphate dehydrogenase in peach leave of various developmental stages. Plant Cell Physiol. 39, 1372-1374. doi: 10.1093/oxfordjournals.pcp.a029344

Salazar-Parra, C., Aguirreolea, J., Sánchez-Díaz, M., Irigoyen, J. J., and Morales, F. (2012). Climate change (elevated $\mathrm{CO}_{2}$, elevated temperature and moderate drought) triggers the antioxidant enzymes' response of grapevine cv. Tempranillo, avoiding oxidative damage. Physiol. Plant 144, 99-110. doi: 10.1111/j.1399-3054.2011.01524.x

Salazar-Parra, C., Aranjuelo, I., Pascual, I., Erice, G., Sanz-Sáez, Á., Aguirreolea, J., et al. (2015). Carbon balance, partitioning and photosynthetic acclimation in fruit-bearing grapevine (Vitis vinifera L. cv. Tempranillo) grown under simulated climate change (elevated $\mathrm{CO}_{2}$, elevated temperature and moderate drought) scenarios in temperature gradient greenhouse. J. Plant Physiol. 174, 97-109. doi: 10.1016/j.jplph.2014.10.009

Salazar-Parra, C., Aranjuelo, I., Pascual, I., Aguirreolea, J., Sánchez-Díaz, M., Irigoyen, J. J., et al. (2018). Is vegetative area, photosynthesis, or grape $C$ uploading involved in the climate change-related grape sugar/anthocyanin decoupling in Tempranillo? Photosynth. Res. 138, 115-128. doi: 10.1007/s11120-018-0552-6

Sami, F., Yusuf, M., Faizan, M., Faraz, A., and Hayat, S. (2016). Role of sugars under abiotic stress. Plant Physiol. Biochem. 109, 54-61. doi: 10.1016/ j.plaphy.2016.09.005

Santana-Veira, D. D. S., Freschi, L., Aragão, L., Henrique, D., Moraes, S., De Neves, D. M., et al. (2016). Survival strategies of citrus rootstocks subjected to drought. Sci. Rep. 6, 1-12. doi: 10.1038/srep38775

Sanz-Sáez, Á., Erice, G., Aguirreolea, J., Irigoyen, J. J., and Sánchez-Díaz, M. (2012). Alfalfa yield under elevated $\mathrm{CO}_{2}$ and temperature depends on the Sinorhizobium strain and growth season. Environ. Exp. Bot. 77, 267-273. doi: 10.1016/ j.envexpbot.2011.11.017

Sanz-Sáez, Á., Erice, G., Aranjuelo, I., Aroca, R., Ruíz-Lozano, J. M., Aguirreolea, J., et al. (2013). Photosynthetic and molecular markers of $\mathrm{CO}_{2}$-mediated photosynthetic downregulation in nodulated alfalfa. J. Integr. Plant Biol. 55, 721-734. doi: 10.1111/ jipb.12047

Scarascia-Mugnozza, G., Calfapietra, C., Ceulemans, R., Gielen, B., Cotrufo, M., De Angelis, P., et al. (2006). "Responses to elevated $\left[\mathrm{CO}_{2}\right]$ of a short rotation, multispecies poplar plantation: the POPFACE/EUROFACE experiment," in Managed ecosystems and $\mathrm{CO}_{2}$ : case studies, processes and perspectives. Ecological Studies 187. Eds. S. Long, R. Norby, M. Stitt, G. Hendrey and H. Blum (Berlin, Heidelberg, Germany: Springer-Verlag), 173-195. doi: 10.1007/ 3-540-31237-4_10

Schefe, J. H., Lehmann, K. E., Buschmann, I. R., Unger, T., and Funke-Kaiser, H. (2006). Quantitative real-time RT-PCR data analysis: Current concepts and the novel "gene expression's CT difference" formula. J. Mol. Med. 84, 901-910. doi: 10.1007/s00109006-0097-6

Serra, I., Strever, A., Myburgh, P. A., and Deloire, A. (2014). Review: The interaction between rootstocks and cultivars (Vitis vinifera L.) to enhance drought tolerance in grapevine. Aust. J. Grape Wine Res. 20, 1-14. doi: 10.1111/ ajgw.12054

Solari, L. I., Johnson, S., and Dejong, T. M. (2006). Hydraulic conductance characteristics of peach (Prunus persica) trees on different rootstocks are related to biomass production and distribution. Tree Physiol. 26, 1343-1350. doi: 10.1093/treephys/26.10.1343

Song, Y., Chen, Q., Ci, D., Shao, X., and Zhang, D. (2014). Effects of high temperature on photosynthesis and related gene expression in poplar. $B M C$ Plant Biol. 14, 111. doi: 10.1186/1471-2229-14-111

Suzuki, Y., and Dandekar, A. M. (2014). Sucrose induces expression of the sorbitol-6-phosphate dehydrogenase gene in source leaves of loquat. Physiol. Plant 150, 355-362. doi: 10.1111/ppl.12106

Szabados, L., and Savoure, A. (2010). Proline: a multifunctional amino acid. Trends Plant Sci. 15, 89-97. doi: 10.1016/j.tplants.2009.11.009

Turner, N. (1986). Adaptation to water deficits: a changing perspective. Aust. J. Plant Physiol. 13, 175-190. doi: 10.1071/PP9860175

Untergasser, A., Nijveen, H., Rao, X., Bisseling, T., Geurts, R., and Leunissen, J. A. M. (2007). Primer3Plus, an enhanced web interface to Primer3. Nucleic Acids Res. 35, 71-74. doi: 10.1093/nar/gkm306 
Verbruggen, N., and Hermans, C. (2008). Proline accumulation in plants: a review. Amino Acids 35, 753-759. doi: 10.1007/s00726-008-0061-6

Vicente, R., Pérez, P., Martínez-Carrasco, R., Usadel, B., Kostadinova, S., and Morcuende, R. (2015). Quantitative RT-PCR platform to measure transcript levels of $\mathrm{C}$ and $\mathrm{N}$ metabolism-related genes in durum wheat: transcript profiles in elevated $\left[\mathrm{CO}_{2}\right]$ and high temperature at different nitrogen supplies. Plant Cell Physiol. 56, 1556-1573. doi: 10.1093/pcp/pcv079

Wu, B. H., Li, S. H., Nosarzewski, M., and Archbold, D. D. (2010). Sorbitol dehydrogenase gene expression and enzyme activity in apple: Tissue specificity during bud development and response to rootstock vigor and growth manipulation. J. Am. Soc Hortic. Sci. 135, 379-387. doi: 10.21273/JASHS.135.4.379

Yu, J., Sun, L., Fan, N., Yang, Z., and Huang, B. (2015). Physiological factors involved in positive effects of elevated carbon dioxide concentration on Bermuda grass tolerance to salinity stress. Environ. Exp. Bot. 115, 20-27. doi: 10.1016/j.envexpbot.2015.02.003
Conflict of Interest: Author SJ was employed by company Bayer AG, though the research was conducted before his employment at the company, in the absence of any conflict of interest.

The remaining authors declare that the research was conducted in the absence of any commercial or financial relationships that could be construed as a potential conflict of interest.

Copyright (c) 2020 Jiménez, Fattahi, Bedis, Nasrolahpour-moghadam, Irigoyen and Gogorcena. This is an open-access article distributed under the terms of the Creative Commons Attribution License (CC BY). The use, distribution or reproduction in other forums is permitted, provided the original author(s) and the copyright owner(s) are credited and that the original publication in this journal is cited, in accordance with accepted academic practice. No use, distribution or reproduction is permitted which does not comply with these terms. 